The Cryosphere Discuss., https://doi.org/10.5194/tc-2017-210

Manuscript under review for journal The Cryosphere

Discussion started: 2 November 2017

(c) Author(s) 2017. CC BY 4.0 License.

\title{
Review article: The hydrology of debris-covered glaciers - state of the science and future research directions
}

\author{
Katie E. Miles ${ }^{1 *}$, Bryn Hubbard ${ }^{1}$, Tristram D. L. Irvine-Fynn ${ }^{1}$, Evan S. Miles ${ }^{2}$, Duncan J. Quincey ${ }^{2}$ and \\ Ann V. Rowan ${ }^{3}$
}

1. Centre for Glaciology, Department of Geography and Earth Sciences, Aberystwyth University, Aberystwyth, UK

2. School of Geography, University of Leeds, Leeds, UK

3. Department of Geography, University of Sheffield, Sheffield, UK

* Correspondence to: kam64@aber.ac.uk

\section{Abstract}

Debris-covered glaciers (DCGs) are characterised by distinct hydrological systems that differ fundamentally from those observed on clean-ice valley glaciers. To date, most studies of DCG hydrology have focused on supraglacial hydrology, given that surface streams are broadly accessible and repeat observations can lead to conceptual models of channel evolution. Few have characterised englacial conduits and their layout, and none have directly investigated potential subglacial drainage networks in any setting. In this review, we summarise the current state of knowledge relating to DCG hydrology with a global focus, and present our own field observations to illustrate the distinct nature of DCG landforms on a receding high-elevation glacier in the Himalaya. We draw on recent work that has gone some way towards providing a process-based understanding of the formation and evolution of englacial and subglacial hydrological pathways and consider the role that DCG hydrology plays in regulating water supplies to downstream communities, contrasting this information with clean-ice examples. We conclude by identifying important knowledge gaps that might be considered priorities for future research into DCG hydrology.

\section{Introduction}

Debris-covered glaciers (DCGs), also referred to as debris-mantled glaciers, moraine-covered glaciers or ice-cored rock glaciers, are present in nearly all of Earth's glacierised regions, with a particularly large concentration in the Himalayan mountain range (Bolch et al., 2012; Scherler et al., 2011). Ice and snow melt from these DCGs represents the source for some of the world's largest rivers: around 25\% of Earth's population is dependent on glacier melt and seasonal snowpacks for drinking water, irrigation and hydroelectric power supplies (Immerzeel et al., 2010). The recent mass loss of glaciers in response to the warming climate is currently increasing river discharge and sea-level contributions (Lutz et al., 2014; Radić et al., 2014; Shea and Immerzeel, 2016), but studies simulating future scenarios are universal in predicting long-term reductions in flow, perhaps as 
The Cryosphere Discuss., https://doi.org/10.5194/tc-2017-210

Manuscript under review for journal The Cryosphere

Discussion started: 2 November 2017

(c) Author(s) 2017. CC BY 4.0 License.

soon as 2050 in central Asia (Barnett et al., 2005; Bolch et al., 2012; Lutz et al., 2014; Ragettli et al., 2016a; Sorg et al., 2012). This may threaten water security in many regions, particularly across High Mountain Asia where most rivers source from glaciers in the Himalaya (Eriksson et al., 2009; Hannah et al., 2005; Immerzeel et al., 2010; Winiger et al., 2005); these glaciers currently reduce vulnerability to seasonal water shortages (Pritchard, 2017). A decreased discharge of the Indus and Brahmaputra rivers alone is estimated to affect 260 million people (Immerzeel et al., 2010).

The long-term response of DCGs to changing climatic conditions is strongly non-linear and reflects both spatial variability in debris concentration and climatic controls integrated over at least several decades (Benn et al., 2012; Vaughan et al., 2013). Predictions of mass loss for individual glacierised regions vary hugely. For example, in the Everest region of the Himalaya, Rowan et al. (2015) predicted an $8-10 \%$ mass loss of glaciers by 2100 , while Soncini et al. (2016) calculated up to a $50 \%$ loss, and Shea et al. (2015) up to 99\% loss in extreme scenarios (warming of $\sim 3^{\circ} \mathrm{C}$ ). At a regional scale, model predictions also vary: Zhao et al. (2014) predicted a $22 \%$ total loss of all glaciers in High Mountain Asia by 2050 (contributing $5 \mathrm{~mm}$ to sea-level rise); Chaturvedi et al. (2014) found that up to $27 \%$ of glaciers in the Himalaya-Karakoram may have ablated completely by 2080 under the most rapid warming scenario; and Kraaijenbrink et al. (2017) found that $36 \%$ of glaciers in High Mountain Asia will be lost by 2100 with only a conservative $1.5^{\circ} \mathrm{C}$ global temperature rise. Clearly, predictions such as these depend sensitively on the precise climate scenario used, but a number of key knowledge gaps also exist concerning the character of DCGs and the processes influencing them (Bolch et al., 2012; Huss, 2011). In particular, due to the remoteness and inaccessibility of such glaciers, hydrological research has been severely limited.

In this review we consider the current state of knowledge of DCG hydrological systems, and highlight key gaps as suggested topics for further research. While the review includes hydrological research relating to DCGs located anywhere on Earth, it is noted that much of this research relates to high-elevation Himalayan DCGs. First (Section 2), we discuss the formation and distribution of DCGs. Next, we present a summary of existing research and understanding of the hydrological systems of DCGs. This is considered in terms of four hydrological domains: supraglacial (Section 3), englacial (Section 4), subglacial (Section 5), and proglacial (Section 6). Finally, in light of the above, we propose several potential future research directions concerning the hydrology of DCGs (Section 7).

\section{Debris-covered glaciers}

Kirkbride (2011) defined a DCG as 'a glacier where part of the ablation zone has a continuous cover of supraglacial debris across its full width'. While this definition has been broadly adopted, we do not necessarily determine that the full width of the glacier terminus must be debris-covered; however, debris must cover a large enough portion of this area to distinguish it from a broad medial moraine (Anderson, 2000). Therefore, we define a DCG herein as 'a glacier with a largely continuous layer of supraglacial debris that covers most of the ablation area, typically increasing in thickness towards the terminus'. Figure 1 shows many of the common features of a typical DCG, both from above (Figure 1A) and obliquely (Figure 1B).

DCGs are present in nearly all glacierised regions, and occur extensively where high rates of rock uplift provide large amounts of sediment through glacial erosion in young mountain ranges 
The Cryosphere Discuss., https://doi.org/10.5194/tc-2017-210

Manuscript under review for journal The Cryosphere

Discussion started: 2 November 2017

(c) Author(s) 2017. CC BY 4.0 License.

such as the Himalaya, Southern Alps and the Andes (Anderson and Anderson, 2016; Dunning et al., 2015). Approximately $23 \%$ of all glaciers across the Himalaya-Karakoram have a debris cover (Scherler et al., 2011), but due to the difficulties in mapping and accessing many glaciers, a global map of DCGs has not yet been published (cf. Sasaki et al., 2016). DCGs have been mapped and observed independently in the European Alps (Brock et al., 2010; Paul et al., 2004), Iceland (e.g. Spedding 2000), Svalbard (e.g. Etzelmüller et al. 2001; Lukas et al. 2005), Scandinavia (e.g. Jansson et al. 2000), Canada (e.g. Mattson 2000), Alaska (e.g. Kienholz et al. 2015), California (e.g. Clark et al. 1994), the High Andes (Emmer et al., 2015; Janke et al., 2015; Racoviteanu et al., 2008), New Zealand (e.g. Kirkbride \& Warren 1999), Iran (e.g. Karimi et al. 2012), Caucasus (e.g. Stokes et al. 2007; Lambrecht et al. 2011) and Antarctica (e.g. Chinn \& Dillon 1987; Levy et al. 2006; Mackay et al. 2014). They are commonly found in areas of mountain permafrost (Schmid et al., 2015), while permafrost-related patterned ground has also been observed on the debris layer of DCGs, for example in Antarctica (Levy et al., 2006).

As well as on Earth, over 1,300 individual DCGs have been both identified (Baker, 2001; Head and Marchant, 2003) and inventoried (Souness et al., 2012) in the mid-latitude regions of Mars. Although currently colder and drier than Earth, Mars' so-called 'glacier-like forms' are similarly lobate, debris-covered, deforming, and able to deposit debris to form bounding moraine ridges. Both the detailed characterisation and broader dynamic glaciology of martian glacier-like forms have been reported elsewhere (Hubbard et al., 2011, 2014), but given there are almost no published data on their hydrological characteristics, planetary DCGs are not considered further herein.

Debris is supplied to a glacier through avalanching, rockfalls and small landslides onto the glacier surface (Figure 2A), thrusting from the bed, dust blown from exposed moraines or solifluction from (ice-cored) moraines (Dunning et al., 2015; Evatt et al., 2015; Gibson et al., 2017a; Hambrey et al., 2008; Kirkbride and Deline, 2013; Kirkbride and Warren, 1999; Rowan et al., 2015; Spedding, 2000). Rockfall triggered by freeze-thaw processes (Nagai et al., 2013), landslides (Hewitt et al., 2008) and permafrost degradation (Gruber and Haeberli, 2007) can also contribute to the accumulation of debris on a glacier surface, and the frequency of such events appears to be increasing with climate change (Gruber et al., 2004; Huggel et al., 2012). Where there is a supply of debris in the accumulation zone, it is often advected into the ice and transported englacially through the glacier along flowlines (Figure 2B); eventually being melted out at the surface in the ablation area (Anderson and Anderson, 2016; Dunning et al., 2015; Evatt et al., 2015; Jansson et al., 2000; Kirkbride and Deline, 2013). The surface of the accumulation zone is therefore commonly largely free from debris, with a thin debris layer emerging at the surface near the equilibrium line and increasing in thickness towards the terminus (Gibson et al., 2017b; Iwata et al., 2000). Debris layers have been noted to develop more quickly, and to expand upglacier (or laterally from medial moraines), during periods of glacier recession (Iwata et al., 2000). Debris can also be entrained subglacially if it is frozen onto cold basal ice (Jansson et al., 2000) or where water is elevated under pressure, triggering a switch from subglacial to englacial drainage and transporting debris up into the glacier (Spedding, 2000).

A debris layer can range in thickness from a few millimetres, comprising scattered particles, to several metres or more, comprising large rocks and boulders (Figure 2C \& D) (Inoue and Yoshida, 
The Cryosphere Discuss., https://doi.org/10.5194/tc-2017-210

Manuscript under review for journal The Cryosphere

Discussion started: 2 November 2017

(c) Author(s) 2017. CC BY 4.0 License.

1980; McCarthy et al., 2017). Direct measurements of thick supraglacial debris layers are difficult to acquire, so published data are scarce. Gades et al. (2000) used radio-echo sounding on Khumbu Glacier, Nepal Himalaya, to measure supraglacial debris up to $3 \mathrm{~m}$ thick; our own observations on the same glacier suggest that in places the debris cover exceeds this thickness (Figure 2D). Satellite imagery has also been used to approximate debris thickness in a variety of settings using debris surface temperature measurements (Gibson et al., 2017b; Rounce et al., 2015): on Miage Glacier in the Italian Alps, for example, the surface debris layer ranged from 0 to $0.6 \mathrm{~m}$ thick (Foster et al., 2012; Mihalcea et al., 2008). Beneath the supraglacial debris layer, glacial ice can include entrained debris (Figure 2B) or be debris-free (Figure 2C) (Schmid et al., 2015).

Several publications have reviewed the hydrology of 'clean-ice' glaciers (e.g. Fountain and Walder, 1998; Hubbard and Nienow, 1997; Irvine-Fynn et al., 2011; Jansson et al., 2003) and ice sheets (e.g. Greenwood et al., 2016). However, these reviews have omitted consideration of the hydrology of DCGs, which is both under-investigated - and consequently very poorly understood and distinctive. This distinctiveness results from several characteristics, including: the presence of supraglacial ponds that appear to interact intimately with near-surface englacial drainage; the presence of a thick debris cover that influences patterns of surface melt and runoff; the possible presence of cold ice advected from high elevation accumulation areas, influencing englacial and subglacial drainage; the presence of a glacier tongue of low, or even reversed, surface slope that would correspondingly influence the local hydraulic potential (Shreve, 1972); the common presence of a substantial moraine-impounded proglacial lake that would also complicate nearterminus englacial and subglacial water flows; and finally, the common location of DCGs in monsoon-influenced areas, affecting temporal patterns of mass balance. Below, we summarise the current information and understanding relating specifically to the hydrology of DCGs.

\section{Supraglacial hydrology}

Supraglacial hydrology includes meltwater generation, and meltwater transport through the debris layer, supraglacial ponds, and supraglacial streams, eventually to be delivered to the glacier's englacial drainage system or off the glacier margin directly to the proglacial zone. Here, we discuss these flowpath components in sequence.

\subsection{Meltwater generation}

Similar to clean-ice glaciers, meltwater on DCGs is produced primarily through ablation of surface ice and snow. However, the spatial pattern of the former is complicated by the presence of surface debris over much of the ablation area of DCGs (Figure 2). Overall, the presence of thick debris tends to suppress ablation. In the Caucasus, for example, debris layers were found to reduce melt by an average of $\sim 25 \%$ compared to clean ice (Lambrecht et al., 2011). This varies primarily with the thickness and lithology of the debris layer (Figure 3). A debris layer thinner than a critical thickness, typically of $\sim 50 \mathrm{~mm}$, will enhance albedo and thus increase the ablation rate compared to debris-free ice. The ablation rate peaks at a debris thickness of $\sim 2-5 \mathrm{~mm}$, known as the 'effective' thickness (Adhikary et al., 2000; Evatt et al., 2015; Inoue and Yoshida, 1980; Juen et al., 2014; Lejeune et al., 2013; Nicholson and Benn, 2006, 2013; Østrem, 1959; Singh et al., 2000; Takeuchi et al., 2000). A debris thickness greater than $\sim 50 \mathrm{~mm}$ instead insulates the ice from 
The Cryosphere Discuss., https://doi.org/10.5194/tc-2017-210

Manuscript under review for journal The Cryosphere

Discussion started: 2 November 2017

(c) Author(s) 2017. CC BY 4.0 License.

incoming solar radiation, increasing the albedo but inhibiting the penetration of excess surface energy to the ice and thus reducing the melt rate (Figure 3). The exact values of the critical and effective thickness are strongly dependent on the thermal conductivity of the debris (Figure 3), which can vary widely across a glacier surface and differs according to whether the debris is wet or dry (Casey et al., 2012; Collier et al., 2014, 2015; Gibson et al., 2017a; Nicholson and Benn, 2013; Pelto, 2000). For example, Kayastha et al. (2000) found that maximum ice ablation occurs beneath a debris layer that is $3 \mathrm{~mm}$ thick on Khumbu Glacier. Variations in ablation according to these factors represent an important first-order control on glacier surface morphology, and are partially responsible for the characteristic hummocky topography of large mounds separated by troughs superimposed upon a concave surface profile of debris-covered surfaces (Figure 1B).

Beneath a debris depth of 250 - $300 \mathrm{~mm}$, the ice becomes almost fully insulated from shortterm surface energy fluxes, and the storage and conduction of heat through the debris layer plays a much greater role in the ablation that occurs (Bocchiola et al., 2015; Brock et al., 2010; Conway and Rasmussen, 2000; Nicholson and Benn, 2013; Østrem, 1959; Reid and Brock, 2010). For example, a thick debris layer comprised of fine-grained particles with a low void space reduces the rate of evapotranspiration driven by air flow at the debris-ice interface, resulting in more energy available for melt (Evatt et al., 2015). Conversely, the presence of moisture in debris layers $>1 \mathrm{~m}$ thick has been found to decrease the efficiency of heat transfer by decreasing the thermal diffusivity of the debris layer, thus reducing heat transmission and melt of the glacier ice below (Collier et al., 2014). Although melt rates beneath thick debris layers are low, they are thus nonnegligible and hence need to be considered in glacier-wide surface energy-balance calculations (Collier et al., 2015).

The ablation rate of DCGs is enhanced by the presence of supraglacial ponds (Section 3.3) and ice cliffs (Figure 2B \& D) that are generally absent from equivalent clean-ice valley glaciers. Supraglacial ice cliffs can form through the slumping of debris from steep slopes, calving at the end of supraglacial ponds, or the collapse of englacial voids (Section 4); all of which expose steep, bare ice faces at the glacier surface (Benn et al., 2001, 2012; Sakai et al., 2002; Thompson et al., 2016). Ice cliffs contribute a notable proportion of the ablation of DCGs (Brun et al., 2016; Buri et al., 2016a; Han et al., 2010; Juen et al., 2014; Reid and Brock, 2014; Sakai et al., 2000, 2002; Thompson et al., 2016), accounting for up to $69 \%$ of the total ablation of debris-covered areas whilst covering as little as $2 \%$ of the total glacier area, exhibiting melt rates often 10-14 times higher than beneath debris-covered ice (Immerzeel et al., 2014; Sakai et al., 1998).

Where ice cliffs are associated with supraglacial ponds, there is further potential for increased melt rates through undercutting and calving processes (Brun et al., 2016; Buri et al., 2016b; Miles et al., 2016a; Röhl, 2008; Thompson et al., 2016). Combined ice cliff and pond systems have been found to contribute significantly to the surface lowering of DCGs (King et al., 2017; Nuimura et al., 2012; Pellicciotti et al., 2015; Ragettli et al., 2016b; Thompson et al., 2016; Watson et al., 2017) and, since it tends to be larger cliffs (and hence greater potential areas for melt) that are associated with ponds (Kraaijenbrink et al., 2016a), this could lead to more rapid glacier surface lowering and meltwater production (King et al., 2017). A decadal trend of surface lowering, stagnation and glacier mass loss has already been observed on a large number of Himalayan DCGs (Bolch et al., 2011, 2012; Kääb et al., 2012; Pellicciotti et al., 2015; Scherler et al., 2011) as a result 
The Cryosphere Discuss., https://doi.org/10.5194/tc-2017-210

Manuscript under review for journal The Cryosphere

Discussion started: 2 November 2017

(c) Author(s) 2017. CC BY 4.0 License.

of warmer air temperatures and weaker monsoons (Pieczonka et al., 2013; Thakuri et al., 2014). Surface lowering rates measured at glaciers in the Everest region were as high as $1.62 \pm 0.14 \mathrm{~m}^{-}$

${ }^{1}$ for high-elevation land-terminating glaciers in the Pumqu catchment between 2000 and 2015 (King et al., 2017). Furthermore, surface lowering on DCGs is leading to an overall increase in debris thickness (Gibson et al., 2017b) and an upglacier emergence of a thin supraglacial debris layer, which will further increase albedo and surface meltwater production (and hence lowering, potentially leading to a positive cycle until debris thickens sufficiently to insulate the surface) (Kirkbride and Warren, 1999; Stokes et al., 2007), but may make observations of subsurface hydrology even more difficult.

\subsection{Debris layer hydrology}

The occurrence of some ice ablation beneath even a thick debris layer implies that during much of the ablation season, water must exist between the ice surface and the debris layer (McCarthy et al., 2017), likely as a thin film. Subsequently, transport of this meltwater must occur, for example as a saturated surface layer or - initially at least - as tiny rivulets. However, despite its importance in contrasting with standard models of supraglacial hydrology based on research at clean-ice glaciers, this process remains unexplored. This at least partly reflects the difficulty involved in gaining non-influencing access to the ice-debris interface beneath thick surface debris. Despite the absence of direct observations, meltwater transport through such a layer is likely to be slow and inefficient, and water may be stored within the debris layer, introducing temporary delays in the transport of meltwater through the system and thus affecting meltwater hydrochemistry (Tranter et al., 1993, 2002), the development of other parts of the drainage network and the proglacial discharge.

However, some parallels may be drawn from comparable systems, such as water flow within debris above and the active layer of permafrost, moraines and talus fields, in order to speculate how this transport may occur. For example, Hortonian overland (or infiltration excess) flow is used to describe initial annual melt in permafrost regions, when frozen soils limit infiltration producing a shallow saturated soil layer, above which overland flow is produced (Woo, 2012; Woo and Xia, 1995). This has been observed within talus fields that are underlain by seasonally frozen, and hence impermeable, ground (Liu et al., 2004) and within the active layer located beneath a layer of debris, with meltwater infiltrating down to, then flowing downslope above the impermeable permafrost table (Rist and Phillips, 2005). Where bedrock or debris is present, water is transported through cracks or spaces between the rocks, but may also follow furrows between linked depressions (Woo, 2012). A similar situation may hold on a smaller scale between impermeable glacial ice and the overlying debris layer, with water flowing in runnels eroded either down into the ice or between rocks in the debris layer. However, any such model remains to be evaluated.

In general, water flow within and below the supraglacial debris layer and across the impermeable supraglacial ice surface would be expected to be directed downglacier towards the terminus and lateral margins (Winter, 2001). Clean-ice glaciers typically have a convex supraglacial geometry, producing clearer watersheds and drainage routes. On DCGs, this pattern is complicated by the presence of hummocky topography and a concave surface profile that commonly results from the reversed mass balance gradient (Bolch et al., 2011), interrupting and complicating these 
The Cryosphere Discuss., https://doi.org/10.5194/tc-2017-210

Manuscript under review for journal The Cryosphere

Discussion started: 2 November 2017

(c) Author(s) 2017. CC BY 4.0 License.

drainage routes (Benn et al., 2017; Miles et al., 2017). Although relatively unexplored, these factors can lead to multiple scales of superimposed hydrological units, from a single supraglacial depression to the full watershed hydrological unit (Winter, 2001).

Moraine-talus features in proglacial environments may also provide a shallow subsurface flow system comparable to water within the supraglacial debris layer on DCGs. Investigation of a moraine-talus feature containing buried ice at Opabin Glacier in the Canadian Rockies demonstrated a system of small channels flowing over the buried ice within the moraine, through the bedrock and talus field beyond the moraine (Roy and Hayashi, 2009). Langston et al. (2011) reported that subsurface ice at the same glacier acted as an impermeable layer causing relatively fast and shallow groundwater flow towards depressions within the proglacial moraine. The water accumulated within these depressions, saturating sediments or surface water features and enhancing the melt of the subsurface ice (Langston et al., 2011). Both of these situations could be plausible within the debris layer of a DCG: meltwater contained within the layer could augment the melt of glacier ice below, or it could initiate and contribute to supraglacial hydrological features such as supraglacial ponds and streams.

\subsection{Supraglacial ponds}

Supraglacial ponds (Figure 4), a term here used to also encompass larger water bodies elsewhere referred to as lakes, are extremely common and important features on DCGs, particularly those with recent surface lowering. Ponds are generally absent from clean-ice valley glaciers, but are prevalent on low-gradient areas of glaciers draining ice sheets; close to the margin the surface is too steep for water to accumulate (Chu, 2014; Sundal et al., 2009). Similarly on a DCG, given a water supply, the most important control on the location of supraglacial pond formation is the slope of the glacier surface, with ponds being most prominent in areas with the lowest gradients (Miles et al., 2016b; Quincey et al., 2007; Reynolds, 2000; Sakai, 2012; Sakai et al., 2000; Sakai and Fujita, 2010; Salerno et al., 2012). A surface gradient of $2^{\circ}$ or less promotes the development of larger lakes; at slopes greater than this threshold, smaller isolated and transient ponds are more likely (Miles et al., 2016b; Quincey et al., 2007; Reynolds, 2000). Salerno et al. (2012) additionally found that the upglacier slope has an influence on pond formation, being inversely correlated to the total area of lakes downglacier.

Glacier velocity and motion type exert less important controls over the location of supraglacial ponds. An increase in lake concentration was reported towards the terminus of DCGs, which is also characterised by low or very low surface velocities (Kraaijenbrink et al., 2016a; Miles et al., 2016b; Quincey et al., 2007; Sakai, 2012; Salerno et al., 2012, 2015). A decrease in velocity towards the glacier terminus, as well as ice inflow at flow unit confluences (Kraaijenbrink et al. 2016b), causes longitudinally compressive flow, which tends to close transverse crevasses and englacial conduits and force water back to the surface, as well as limiting drainage from the glacier surface (Kraaijenbrink et al., 2016a; Miles et al., 2016b). The thinning and stagnation of DCG termini may additionally have resulted in enhanced melting beneath the debris layer, further promoting the formation of ponds (Salerno et al., 2015; Thakuri et al., 2016).

Initial supraglacial pond growth occurs through subaqueous melting at the base of any slight depression (Chikita et al., 1998; Mertes et al., 2016; Miles et al., 2016a; Stokes et al., 2007; 
The Cryosphere Discuss., https://doi.org/10.5194/tc-2017-210

Manuscript under review for journal The Cryosphere

Discussion started: 2 November 2017

(c) Author(s) 2017. CC BY 4.0 License.

Thompson et al., 2012). Once water has accumulated and been warmed by incoming solar radiation, the pond becomes warmer than the surrounding ice. For example, Chikita et al. (1998) measured a maximum temperature of $\sim 5^{\circ} \mathrm{C}$ at the surface of a supraglacial lake on Trakarding Glacier, Nepal Himalaya. Excess energy is thus available for further ablation both vertically and laterally where the pond water is in contact with ice, increasing the pond size, steepening marginal slopes and mobilising debris to expose bare ice (Stokes et al., 2007). Xin et al. (2012) observed on Koxkar Glacier, Tien Shan mountains, that meltwater at $0^{\circ} \mathrm{C}$ flowing into a pond initially cooled the surface layer, but gradually mixed with warmer, deeper layers and warmed to $\sim 4^{\circ} \mathrm{C}$. This increased the layer's density, causing it to sink and therefore move the warmer water towards the base of the pond, providing greater potential for additional subaqueous melting. In addition, wind-driven currents promote water circulation and vertical transfer of heat downwards, further enhancing basal melt of the pond (Chikita et al., 1998).

Many supraglacial ponds are surrounded by ice cliffs (Figure 4) where ponds can expand by subaerial melting and backwasting of the bare ice face (Röhl, 2008). Pond stratification and winddriven currents may further enhance the subaqueous melt expansion of supraglacial ponds by triggering calving of the ice cliffs. The warm surface layer of the pond is disrupted by wind-driven currents, and where it come into contact with glacier ice, can undercut the cliff beneath the waterline. Progressive undercutting and thermo-erosional notch development may then lead to calving of the ice cliff face (Chikita et al., 1998; Kirkbride and Warren, 1997; Mihalcea et al., 2006; Miles et al., 2016a; Röhl, 2006, 2008; Sakai et al., 2009). Ice cliff calving occurs when the subaqueous melt rate exceeds the ice cliff melt rate; this is noted to be effective when the fetch is greater than $20 \mathrm{~m}$ and the water temperature is $2-4^{\circ} \mathrm{C}$, though is possible at lower values (Sakai et al., 2009). Calving expansion is particularly effective at larger ponds (Röhl, 2008).

Calving events cause further mixing of pond layers, driving warmer surface water towards the base and again enhancing basal melting. Thompson et al. (2012) reported that the largest deepening rates of a supraglacial pond on Ngozumpa Glacier, Nepal Himalaya, occurred adjacent to the highest calving ice cliffs. Furthermore, when debris that has been heated by solar radiation falls into a pond, it contributes to the energy available for melt around the pond base (Thompson et al., 2012). Although shallowing of ponds can occur by sedimentation from inflowing water, this tends to be outstripped by growth caused by ablation (Thompson et al., 2012).

A pattern of supraglacial pond evolution has been observed on DCGs, primarily based on observations in the Himalaya. According to this model, supraglacial ponds form as 'perched ponds' that lie above the englacial drainage network (Benn et al., 2012). As these ponds increase in area and depth, they evolve from perched to base-level features, where the base-level is determined by the height at which water leaves the glacial system (usually the elevation of a spillway through the moraine at the glacier terminus or even the bed if water is transported there) (Mertes et al., 2016; Thompson et al., 2012). However, differing sub-catchments may have differing base-levels defined by other hydrological features such as moulins, which can result in a stepped hydrological cascade based on these local base-levels; alternatively, the presence of a groundwater system can produce a regional base-level. Where glaciers are in recession, an increasing number of supraglacial ponds will form and grow over time, creating a chain of terminus-base-level lakes that coalesce as each individually increases in area (Figure 1) (Sakai, 2012; Salerno et al., 2012). The 
The Cryosphere Discuss., https://doi.org/10.5194/tc-2017-210

Manuscript under review for journal The Cryosphere

Discussion started: 2 November 2017

(c) Author(s) 2017. CC BY 4.0 License.

growth of base-level lakes is not limited by periodic drainage, and so such lakes can potentially increase exponentially in area, particularly through calving processes (Benn et al., 2001; Sakai, 2012; Thompson et al., 2012). If meltwater cannot escape from the system, lake expansion and coalescence will eventually lead to the formation of a single base-level moraine-dammed lake at the terminus (Mertes et al., 2016), that will then continue to expand both upglacier and downwards by ice melt. Water can escape the system by permeating through or flowing over the terminal moraine in a proglacial outlet spillway as the lake fills with sediment, or in rare instances the moraine dam may fail causing the lake to drain (Benn et al., 2001, 2012; Chikita et al., 2001; Sakai, 2012).

The progression of supraglacial pond evolution can currently be observed at various stages on many Himalayan glaciers. Several regions have experienced an increase in supraglacial pond area and proglacial lake formation in recent decades, assumed to be in response to a warmer climate and glacier surface lowering, for example glaciers in the Tian Shan mountains (Wang et al., 2013), Bhutan Himalaya (Ageta et al., 2000; Komori, 2008), Nepal Himalaya (Benn et al., 2000; Watson et al., 2016), New Zealand (Kirkbride and Warren, 1999; Röhl, 2008) and the Andes (Harrison et al., 2006; Rivera et al., 2007). Within the Hindu-Kush Himalaya, a clear divide has appeared between glacial lakes in the East, where there are a greater number of larger lakes that have grown progressively between 1990-2009 to become increasingly proglacial, compared to the western Himalaya, where smaller supraglacial lakes have generally been decreasing in area (Gardelle et al., 2011).

As isolated perched ponds widen and deepen, they can become connected to the englacial system by deepening to a point where they intersect englacial drainage channels and drain rapidly (Benn et al., 2001; Qiao et al., 2015; Röhl, 2008; Watson et al., 2016; Wessels et al., 2002), which temporarily halts the process of pond expansion (Mertes et al., 2016). Drainage then occurs periodically in a cycle of expansion and englacial connection, unlike larger, permanently hydraulically connected ponds, which tend to be more stable due to inputs of meltwater from streams and other ponds farther upglacier (Benn et al., 2001; Miles et al., 2017; Wessels et al., 2002). An abundant supply of meltwater from the ice surface or the wider drainage system is indicated by ponds with a high suspended sediment concentration (SSC); these ponds may also expand more rapidly due to the increased presence of warmer water for ablation of the pond walls (Takeuchi et al., 2012). Narama et al. (2017) observed a seasonal pattern of supraglacial pond filling and drainage, with $94 \%$ of their observed ponds over seven glaciers draining between 2013-2015. Pond seasonality has also been noted by Miles et al. (2016b), who found the maximum ponded area of five glaciers in the Langtang Valley, Nepal Himalaya, to occur during June for the study period 1999-2013. Larger ponds were also observed to partly drain and separate into multiple, smaller ponds, and later refill to form one large pond (Benn et al., 2001; Miles et al., 2016b; Wessels et al., 2002). Warmer temperatures during the spring months have been noted to correlate with a greater number of drainage events later in the same year, potentially due to the subsurface drainage system becoming increasingly connected from a greater amount of meltwater earlier in the year (Qiao et al., 2015).

Pond drainage is promoted in zones of higher local surface velocity and hence strain rates, creating a greater connectivity between the supraglacial and englacial drainage networks; more 
The Cryosphere Discuss., https://doi.org/10.5194/tc-2017-210

Manuscript under review for journal The Cryosphere

Discussion started: 2 November 2017

(c) Author(s) 2017. CC BY 4.0 License.

frequent drainage in such regions results in smaller-sized ponds (Miles et al., 2016b). However, as noted earlier in this section, ponds are more likely to form in areas with lower surface velocities. Ponds may also drain by preferentially exploiting inherited structured weaknesses such as sediment-filled crevasse traces, crevasses and englacial channels that have been forced closed in regions of longitudinal compression, allowing drainage by hydrofracture (the penetration of a water-filled crevasse through an ice mass assisted by the additional pressure of the water at the crevasse tip) (Benn et al., 2009, 2012, 2017; Gulley and Benn, 2007; Miles et al., 2016b). Alternatively, perched ponds may drain by overspilling, when a channel is melted into the downstream end of a pond; if, during drainage, this channel incises faster than the pond level decreases then unstable and potentially catastrophic drainage can result (Qiao et al., 2015; Raymond and Nolan, 2000). Analyses on Lirung Glacier, Nepal Himalaya, provided strong evidence of continuous inefficient drainage of supraglacial ponds, likely into debris-choked englacial conduits (Miles et al., 2017).

Supraglacial ponds are responsible for a large proportion of the melt from DCGs. Sakai et al. (2000) estimated that ponds on Lirung Glacier absorb seven times more heat than the ice beneath the debris-covered area, with at least $50 \%$ of this released with the melt output from the pond. Miles et al. (2016a) found that subaqueous melt rates can keep pace with the backwasting of ice cliffs, enabling these systems to propagate, and enabling the ice cliff to persist and backwaste stably (Brun et al., 2016; Buri et al., 2016b). Both Sakai et al. (2000) and Miles et al. (2016a) inferred that ponds have a strongly positive surface energy balance, and the warm water they discharge contributes to internal melting along englacial conduits. This in turn leads, in some cases, to roof collapse and the formation of new ponds (Benn et al., 2012; Miles et al., 2016a; Sakai et al., 2000), resulting in a net glacier-wide increase in ablation rate. Salerno et al. (2012) stated that the increasing presence of ponds is the clearest indicator of the effect that climate change is having on DCGs.

\subsection{Supraglacial streams}

Supraglacial streams are commonly difficult to discern in debris-covered or crevassed regions of the glacier surface, and therefore are rarely recorded in the literature. Large streams can be traced in the upper reaches of some glaciers in satellite imagery, but small surface streams and diffuse flows are less easily located and thus their prevalence remains unreported. For streams to form and grow, a large catchment is required (Benn et al., 2017; Gulley et al., 2009a) and the rate of stream downcutting must outpace the rate of surface lowering (Marston, 1983). Such conditions may be promoted beneath thick debris with the ability to suppress surface ablation (Benn et al., 2017). However, the presence of supraglacial streams has been recorded, ranging from small temporary incisions to large perennial channels (Figure $5 \mathrm{~A}-\mathrm{C}$ ). Stream growth and downcutting is driven by thermal erosion (Marston, 1983) and can be marked by grooves down the side of the channel showing previous high water-levels (Figure 5C); in extreme cases, ice cliffs form either side of the stream. While such cliffs form on clean-ice glaciers, the relief of those on DCGs appears to be more pronounced (Figure 5C \& D), probably due to the debris-related suppression of surface lowering away from surface streams.

Supraglacial streams have been noted originating in the upper ablation area of Khumbu Glacier, for example beneath the ice fall, with at least one perpetual feature visible in several years 
The Cryosphere Discuss., https://doi.org/10.5194/tc-2017-210

Manuscript under review for journal The Cryosphere

Discussion started: 2 November 2017

(c) Author(s) 2017. CC BY 4.0 License.

of satellite imagery (Gulley et al., 2009a). These streams seldom intersected with supraglacial ponds, instead progressively eroding into the debris layer with notable rates of downcutting: one stream was 5-10 $\mathrm{m}$ deep when it reached the lower ablation area where the debris layer is substantially thicker (Gulley et al., 2009a; Iwata et al., 1980). In this region, streams enter the glacier's interior; the nature of the entry point is unknown (Iwata et al., 1980). This is supported by our observations of a large supraglacial stream on Khumbu Glacier (Figure 5A \& B) which begins to downcut into the glacier surface in the upper-mid ablation area and eventually disappears and becomes englacial in the mid-ablation area (Figure 5D), although the exact point of transition cannot be seen due to the presence of supraglacial debris and layers of older relict channels.

Similar to regions of clean-ice, supraglacial streams may drain into DCGs through crevasses or moulins (Gulley et al., 2009a; Iwata et al., 1980), or incise to a depth that they develop a closed roof through snow and debris accumulation combined with ice creep (Gulley et al., 2009a; Jarosch and Gudmundsson, 2012). However, supraglacial streams on DCGs differ from those on clean-ice glaciers due to the former's commonly reversed surface profile (Section 3.1). Such features are therefore often interrupted by crevasses or hummocky topography, and may not persist a long way along the glacier (Benn et al., 2017). Low surface gradients, low strain and longitudinal compression reduce the capacity for crevassing in the lower ablation area of heavily debriscovered tongues, where crevasses are therefore rarely encountered. Farther upglacier, often under conditions of strong longitudinal extension associated with ice falls, open crevasses are common and may suppress supraglacial stream development (Benn et al., 2017).

\section{Englacial hydrology}

There are relatively few observations of englacial drainage systems within DCGs, either directly or indirectly inferred. However, as most DCGs have a steep and variable surface gradient in their accumulation and upper ablation zones, crevassing can be prevalent, providing a route for supraglacial stream water to access the interior of the glaciers.

A glacier's thermal structure determines the water content of englacial ice, thereby exerting a primary control on the ability of an englacial hydrological system to form. Glacial ice can be defined as: cold (ice temperature below the pressure melting point); warm (temperature at the pressure melting point); or polythermal (zones of warm and cold ice). Glaciers with a polythermal structure can be further subdivided into several categories depending on the location of the boundary between the warm and cold ice (Blatter and Hutter, 1991). Glaciers with a higher warm ice content are more likely to contain a defined englacial hydrological system, as cold ice near the surface can limit, but not necessarily completely preclude, the penetration of meltwater into the glacial drainage system (Irvine-Fynn et al., 2011). Unfortunately, very few studies have determined the thermal structure of DCGs, and therefore little is known about whether and how water may route through these ice masses. Mae et al. (1975) measured an ice temperature of $-5.3^{\circ} \mathrm{C}$ at $2.7 \mathrm{~m}$ depth within a borehole in the upper ablation area of Khumbu Glacier. By assuming that the ice temperature would increase with depth, they estimated the ice would reach pressure melting point at $16 \mathrm{~m}$ depth, and below this be warm-based to the bed (Mae, 1976; Mae et al., 1975). Similar assumptions were made for Rongbuk Glacier, Tibet, where ice temperatures were measured to a depth of $10 \mathrm{~m}$ (Academica Sinica, 1975). At a depth of $3 \mathrm{~m}$, the ice temperature was 
The Cryosphere Discuss., https://doi.org/10.5194/tc-2017-210

Manuscript under review for journal The Cryosphere

Discussion started: 2 November 2017

(c) Author(s) 2017. CC BY 4.0 License.

$-4^{\circ} \mathrm{C}$ and continued to increase with depth. However, since none of these studies was able to measure temperature at a depth beyond that influenced by seasonal variations in air temperature ( 10-15 m), the influence cannot be isolated. The assumption of a continued temperature increase to the pressure melting point with depth may also not be valid.

Techniques involving proglacial water properties have allowed some inferences to be drawn relating to the existence of englacial drainage systems within DCGs. Hydrological studies of surface mass balance components of Biafo Glacier, Karakoram Himalaya, allowed Hewitt et al. (1989) to infer water storage within the glacier at the start of the melt season, between the time of initial meltwater production and the subsequent reactivation/development of the drainage system. Hydrogeochemical analyses, particularly based on meltwater electrical conductivity (EC), have also been used to infer drainage pathways. Englacially-transported water has a lower sediment and ionic chemical content than subglacially-transported water, which entrains particles and solutes during contact with freshly-eroded basal debris, and therefore displays higher ionic concentrations, and hence EC values (Kumar et al., 2009). Consequently, studies have utilised this binary classification of low-EC supraglacially- and englacially-routed water as opposed to high-EC subglacially-routed water to attribute, via a mixing model, the proportions of water flowing through each system. For example, Hasnain \& Thayyen (1994) used such a method to determine and differentiate between the englacial and subglacial components of the proglacial discharge of Dokriani Bamak Glacier, Garhwal Himalaya. Englacially, they found an efficient system that was active through the melt season, and that the amount of meltwater transport was proportional to supraglacial water production, implying a direct link between these systems. However, despite the evident utility of this approach, the assumption underpinning such mixing models has been questioned. Glacier drainage systems are inherently more complex than comprising only two principal pathways, and the solute content and degree of subglacial weathering can vary at a number of timescales (Sharp et al., 1995).

Englacial water storage and transport has been inferred from measurements of supraglacial pond water-levels, and an assumed connection between the pond and an englacial channel. Thakuri et al. (2016) measured a constant water-level in Imja Tsho lake on Imja Glacier, Nepal Himalaya, after the melt season, despite reduced precipitation and air temperatures, implying decreasing meltwater production. The authors attributed this to a lake recharge from englacially- and subglacially-stored water that was being progressively released over time. Further, the repeated filling and drainage cycle of perched ponds suggests that englacial conduits may play an important role in perched lake life cycles (Benn et al., 2017; Miles et al., 2017). Narama et al. (2017) found that the seasonal drainage cycle of supraglacial ponds on seven glaciers in the Tien Shan was characterised by a connection to an established englacial drainage system later in the summer: $94 \%$ of lakes drained and connected to an englacial system on all three years studied. Benn et al. (2012) proposed that the influx of large volumes of monsoon precipitation during the summer months may result in the opening of englacial (and subglacial) conduits, leading to the potential for considerable englacial ablation, subsequently calculated by Miles et al. (2016a) to be $\sim 2600 \mathrm{~m}^{3}$ for a surface pond of $500 \mathrm{~m}^{2}$ over a single monsoon season.

There have been a number of direct observations of englacial channels using glaciospeleological techniques to explore and map conduits, and subsequently formulate theories 
The Cryosphere Discuss., https://doi.org/10.5194/tc-2017-210

Manuscript under review for journal The Cryosphere

Discussion started: 2 November 2017

(c) Author(s) 2017. CC BY 4.0 License.

of channel development. Glaciolospeleology has been carried out on several DCGs primarily in the Nepal Himalaya, including Khumbu Glacier (Gulley et al., 2009a), Ngozumpa Glacier (Benn et al., 2009, 2017; Gulley and Benn, 2007), Ama Dablam and Lhotse Glaciers (Gulley and Benn, 2007), and several DCGs in the Tien Shan (Narama et al., 2017). These investigations have provided direct confirmation of a linked supraglacial-englacial system, often created by the drainage of supraglacial ponds through englacial conduits (Gulley and Benn, 2007; Narama et al., 2017). On Southern Inylchek Glacier, Tien Shan mountains, Narama et al. (2017) discovered both short englacial channels linking chains of supraglacial ponds and longer channels with steeper gradients extending from surface moulins. The latter may occur at the hydrological base-level of the glacier, and show multiple levels of incision from progressive supraglacial pond drainages over time as the base level has been eroded downwards (Gulley and Benn, 2007). Similar observations have been made on Khumbu Glacier (Gulley et al., 2009a); however, Gulley \& Benn (2007) noted that conduits at different elevations may have varying local base-levels (Section 3.3). In such scenarios, this may suggest that a subglacial drainage system either does not exist beneath the glacier, or is not linked to the englacial system, or re-emerges to base level. Such scenarios, however, remain unreported.

Three formation mechanisms for englacial channels within DCGs have been proposed, primarily from glaciospeleological investigations (Gulley et al., 2009a):

(I) 'Cut-and-closure' type conduits begin as supraglacial streams that incise downwards over time, followed by roof closure through ice creep and supplemented by filling with snow, ice and debris (Jarosch and Gudmundsson, 2012). This process requires a high meltwater discharge such that downward incision is more rapid than glacier surface ablation. Under such conditions, downcutting will continue to the hydrologic base-level of the glacier (Gulley et al., 2009a). Cut-and-closure type conduits have been reported by Gulley et al. (2009) on Khumbu Glacier, and Thompson et al. (2012) on Ngozumpa Glacier. These conduits may be subject to repeated cycles of abandonment and reactivation as water supply varies through the year, with abandoned channels closing by ice creep. However, such channels rarely close completely due to their shallow depth, and may be filled with sediment traces which provide lines of secondary permeability by which the channel can be reactivated (Benn et al., 2009; Gulley and Benn, 2007; Gulley et al., 2009a).

(II) Meltwater may aggregate to form englacial channels by exploiting lines or planes of secondary permeability; for example those left by relict cut-and-closure channels, or debris-filled and/or compressed former surface crevasses (Benn et al., 2012; Gulley and Benn, 2007; Gulley et al., 2009b). This may also be one mechanism by which perched supraglacial ponds can drain (Miles et al., 2017). Along these low-permeability zones, discharge through the icy matrix leads to the development of enlarging lines of preferential flow due to viscous dissipation, eventually forming a phreatic conduit (Benn et al., 2012).

(III) Englacial channels may also form by hydrofracturing (Benn et al., 2009, 2012; Gulley et al., 2009b). However, this is considered to be uncommon on DCGs as it requires surface runoff to enter an open crevasse and is therefore generally restricted to elevations above the debris-covered areas of DCGs (Benn et al., 2012). Nonetheless, channel formation by hydrofracturing has been reported on Khumbu Glacier, where the 
The Cryosphere Discuss., https://doi.org/10.5194/tc-2017-210

Manuscript under review for journal The Cryosphere

Discussion started: 2 November 2017

(c) Author(s) 2017. CC BY 4.0 License.

channels formed within a region of strong transverse extension that resulted in the formation of longitudinal crevasses (Benn et al., 2009, 2012). In such zones, repeated hydrofracturing is encouraged by the combined effect of elevated water pressure in the base of a supraglacial lake with transverse stresses, producing successively lower niches in the walls indicating multiple stages of hydrofracturing followed by channel closure by freeze-on (Benn et al., 2009).

Longer-distance water transport has also been observed through perennial sub-marginal channels located along the edge of DCGs, likely formed by cut-and-closure of supraglacial channels (Benn et al., 2017; Thompson et al., 2016). Gulley \& Benn (2007) suggested that such marginal features could provide longer-distance and more hydraulically efficient pathways than shallower englacial conduits that occur more centrally within the glacier, due to the frequent presence of infilled crevasse traces that can be exploited by water flowing at the margins. Centrally-located englacial conduits are more likely to be discontinuous in nature, as a result of enhanced surface lowering which can expose part of a conduit and re-route the water back to the surface (Figure 6) (Miles et al., 2017).

Englacial conduits within DCGs may increase in efficiency through the melt season, as water transported through the channels provides additional energy for melt and consequently erodes the channel walls (Miles et al., 2016b, 2017; Sakai et al., 2000). For englacial channels located near the surface, rapid expansion can result in conduit collapse as the roof is not sufficiently supported, with the conduit walls forming ice cliffs and contributing to more rapid surface lowering of the glacier surface (Benn et al., 2017; Kraaijenbrink et al., 2016a; Miles et al., 2016a; Sakai et al., 2000; Thompson et al., 2016, 2012). Pond drainage events can further accelerate this process, as well as adding to the total glacier mass loss as the drained water conveys large amounts of energy, contributing to more rapid erosion of the conduit walls (Sakai et al. 2000; Benn et al. 2012; Miles et al. 2016a; Thompson et al. 2016). Rounce et al. (2017) observed an outburst flood at Lhotse Glacier, Nepal Himalaya, which they attributed to be at least partly triggered by the release water stored in englacial conduits that became overburdened during the transitional pre-monsoon season, when meltwater production is increasing and the subsurface hydrology is not fully developed.

Englacial conduit collapse, or closure in areas of transverse compression, can provide new depressions for supraglacial ponds to form, or facilitate the formation of larger lakes (Benn et al., 2001, 2012; Kirkbride, 1993; Kraaijenbrink et al., 2016a; Sakai et al., 2000; Thompson et al., 2012). Conduit collapse results in new bare ice faces, including ice cliffs, where melt rates will be enhanced and the depression may become flooded by that increased meltwater production supplementing inputs from upglacier (Benn et al., 2012). The enhanced ablation of both the meltwater retained within the depression, and the surrounding newly-formed ice cliffs (the old channel walls), will accelerate the melt and surface subsidence of the glacier (Thompson et al., 2012).

\section{Subglacial hydrology}

Almost nothing is known about the subglacial drainage of DCGs due to the difficulties in accessing such systems, resulting in no direct measurements to date. Further, the existence of base-level 
The Cryosphere Discuss., https://doi.org/10.5194/tc-2017-210

Manuscript under review for journal The Cryosphere

Discussion started: 2 November 2017

(c) Author(s) 2017. CC BY 4.0 License.

englacial streams and a perched water table are highly likely to complicate the detection of, and distinction between, englacial and subglacial systems, at least approaching the terminus of DCGs. Furthermore, the majority of reported DCGs terminate in ponds as a result of progressive surface lowering (Section 3.3). This both increases the likelihood of some form of subglacial drainage but at the same time reduces the likelihood of that system being channelised and severely hampers its direct access. An additional complication arises from the high-elevation of some DCG source areas, making it possible that the ice may be too cold throughout for water to penetrate to the bed.

Nonetheless, remote sensing-based (Quincey et al., 2009) and field-based GPS (Bartholomaus et al., 2008, 2011) studies of DCG surface velocities have inferred the occurrence of basal sliding, which requires the presence of lubricating meltwater at the ice-bed interface. While cold-based glaciers are frozen to the bed and move primarily by internal ice deformation and creep (Glen, 1955; Nye, 1957; Weertman, 1983), glaciers with warm basal ice conversely have water present at the bed, partly from pressure melting, and can move at greater speeds through an additional basal motion component (Kamb, 1970; Nye, 1969; Weertman, 1957), either at the rock-ice interface or from deformation of soft sediment (Boulton and Hindmarsh, 1987; Walder and Fowler, 1994). Relatively rapid surface velocities, most notably in the central areas of glaciers and in the summer months (when melting and rainfall delivery are greatest) (Figure 7) have been recorded, for example, by Copland et al. (2009) who recorded a maximum velocity of $>200 \mathrm{~m} \mathrm{a}^{-1}$ on the South Skamri Glacier, Pakistan Karakoram. Such velocity increases have been interpreted as indicative of basal motion lubricated by the presence of subglacial meltwater (Copland et al., 2009; Kääb, 2005; Kodama and Mae, 1976; Kraaijenbrink et al., 2016b; Kumar and Dobhal, 1997; Mayer et al., 2006; Quincey et al., 2009). For some high-elevation DCGs, whose ablation areas often include the base of ice falls, heavy crevassing may provide one route for water to access the internal and basal drainage system of the glacier even if the ice is too cold for an englacial system to reach the bed (Kodama and Mae, 1976). Although rare, such pathways can persist and lead to the formation of moulins, which have occasionally been observed in the upper ablation areas of glaciers, for example on Baltoro Glacier in the Pakistan Karakoram (Quincey et al., 2009), and provide a direct connection to the bed. If meltwater can penetrate to the bed, it not only suggests that the basal conditions are above the pressure melting point (at least locally), but that subsurface hydrological systems are possible and even likely. However, to date very few measurements of the internal or basal ice temperature of DCGs have been made (Section 4).

Further support for the existence of channelised subglacial drainage, at least near the terminus of DCGs, is provided by the presence of single outlet channels at such glaciers. These also discharge large volumes of heavily debris-laden water implying that the water had been transported along the bed, entraining sediment (Quincey et al., 2009). On Ngozumpa Glacier, Benn et al. (2017) interpreted spatially localised seasonal variations in glacier surface velocity as basal sliding and inferred from this the presence of channelised subglacial drainage in the lower $10 \mathrm{~km}$ of the glacier. Whether these fluctuations resulted from basal sliding and/or subglacial till deformation is unknown in the absence of knowledge of subglacial conditions at the glacier (Benn et al., 2017). 
The Cryosphere Discuss., https://doi.org/10.5194/tc-2017-210

Manuscript under review for journal The Cryosphere

Discussion started: 2 November 2017

(c) Author(s) 2017. CC BY 4.0 License.

The existence of active subglacial drainage has additionally been inferred from bulk meltwater analysis. Hasnain \& Thayyen (1994) used EC measurements of the proglacial discharge of Dokriani Bamak Glacier to argue for a perennially-active subglacial system that is interconnected with the englacial system. On the same glacier, Hasnain et al. (2001) used dye-tracing studies to investigate the subglacial drainage system, inferring a possible switch between an inefficient and an efficient drainage system, as has been observed on lower-elevation alpine glaciers (Mair et al., 2002; Nienow et al., 1998). The same methods were used on Gangotri Glacier, Garhwal Himalaya, to show that an efficient channelised system exists at atmospheric pressure and develops through the melt season with increasing meltwater inputs (Pottakkal et al., 2014). Wilson et al. (2016) inferred a large amount of subglacial meltwater storage on Lirung Glacier, compared to the debrisfree Khimsung Glacier, Nepal Himalaya, due to the smaller magnitude of diurnal discharge variability from the former. Bhatt et al. (2007) measured higher solute $\left(\mathrm{Ca}^{2+}\right.$ and $\left.\mathrm{SO}_{4}{ }^{2-}\right)$ concentrations in the proglacial discharge of Lirung Glacier compared to those in the supraglacial ponds on the glacier, inferring that these chemical species were acquired through contact with reactive debris during subglacial drainage.

The particle-size distribution of sediment suspended within the proglacial stream of Gangotri Glacier was interpreted in terms of the waterborne evacuation of subglacially-eroded fines (Haritashya et al., 2010). Both the net flux and size of the suspended particles increased through the melt season, implying that the glacier's drainage system became progressively more competent and interconnected through the melt season.

Thus, although several lines of investigation point to the likely existence of subglacial drainage beneath DCGs, evidence to date has been invaluable, but - in the absence of first-hand access - necessarily inferential and ambiguous.

\section{Proglacial hydrology}

\subsection{Proglacial lakes and GLOFs}

Proglacial lakes predominantly form by a continuation of the processes of glacier thinning and supraglacial pond growth, as described in Section 3.3. Perched supraglacial ponds grow both downwards, eventually cutting to base-level, and laterally, with many lakes eventually coalescing to produce one large lake above and over the terminus (Figure 8) (Kattelmann, 2003; Mertes et al., 2016; Röhl, 2008; Watanabe et al., 2009). Base-level lakes that penetrate the full glacier thickness can form farther upglacier and expand downglacier through the isolated stagnant terminus ice, for example Imja Lake on Imja Glacier (Watanabe et al., 2009), though this is less common and perhaps reflects stagnant ice towards the terminus acting as a flow impediment. The exact location of such a proglacial lake may also be determined by the location of shallow englacial conduits that provide pre-existing lines of weakness as the perched ponds grow (Benn et al., 2017; Thompson et al., 2012). Proglacial lakes will therefore be at the hydrological base-level of the glacier, and are often dammed by the terminal moraine (Thompson et al., 2012). With time, such lakes continue to erode downwards into the ice, eventually reaching bedrock or basal sediment. Hooker Lake, New Zealand Southern Alps (Figure 8), which initially formed in 1994 in front of Hooker Glacier is now approximately $2.5 \mathrm{~km}$ long, $500 \mathrm{~m}$ wide, and has a maximum water depth of $140 \mathrm{~m}$ (Robertson et al., 2012). 
The Cryosphere Discuss., https://doi.org/10.5194/tc-2017-210

Manuscript under review for journal The Cryosphere

Discussion started: 2 November 2017

(c) Author(s) 2017. CC BY 4.0 License.

The formation of moraine-dammed proglacial lakes characterises a further and final stage in the surface lowering and overall mass loss of DCGs. Benn et al. (2012) defined three stages in the development of DCGs: in regime one, all parts of the glacier are dynamically active; in regime two, surface lowering has begun and ice velocities decrease; in regime three, glaciers are completely stagnant and rapid recession may occur. The formation of base-level lakes indicates that a glacier has entered this third regime, and rapid recession may then occur through further expansion of this proglacial lake (Benn et al., 2012). An increasing number of lakes of increasing size have been observed in recent decades around the world (Carrivick and Tweed, 2013), for example in the Caucasus Mountains (Stokes et al., 2007) and across the Himalaya (Gardelle et al., 2011; Thompson et al., 2012). However, the pattern of proglacial lake formation has varied across the Himalaya, with glacial lake coverage in the western Himalaya decreasing $30-50 \%$ from $1990-$ 2009 compared to an increased area of $20-65 \%$ in the eastern Himalaya, concurrent with the much greater observed glacial mass loss in the former region over this period (Gardelle et al., 2011).

Proglacial lakes continue to expand through similar mechanisms to supraglacial ponds until they are limited by subglacial topography, enhancing glacial mass loss and thus meltwater production where the lake is underlain by ice (Carrivick and Tweed, 2013; Röhl, 2008). Initial growth occurs through subaqueous melting and subaerial ice-face melting, causing both deepening and areal growth, but once calving is triggered it becomes the dominant method of lake growth (Röhl, 2008; Thompson et al., 2012). Calving from a proglacial lake progresses from notchdevelopment and roof collapse to large-scale, full-height slab calving that can substantially increase mass loss from a glacier (Kirkbride and Warren, 1997; Thompson et al., 2012). If the lake deepens to the glacier bed, allowing full-height slab calving, the lake may become unstable because the water depth will be sufficient to trigger extending flow in the now-unsupported ice cliff (Kirkbride and Warren, 1999; Thompson et al., 2012). This may weaken the ice by forming crevasses, and allow the ice cliff to calve at a faster rate again; several kilometres of such rapid calving was reported by Kirkbride \& Warren (1999) for Tasman Glacier, New Zealand Southern Alps. The process could also result in an upglacier expansion of the lake (Watanabe et al., 2009), which may have implications for the glacier's drainage system, such as by earlier interruption of meltwater routing (Carrivick and Tweed, 2013).

Very large proglacial lakes can alter a glacier's microclimate, due to a lake's lower albedo and higher thermal heat capacity relative to surrounding ice and soil surfaces, producing relatively cooler summer air temperatures and warmer autumn temperatures (Carrivick and Tweed, 2013). This can slow summer ice ablation and consequently reduce the amount of meltwater being produced and transported through the glacier, with implications for the development of englacial and subglacial drainage systems. If a moraine-dammed proglacial lake is present then the overwhelming majority of water transported through a DCG will pass through it (Benn et al., 2017). This has implications for water drainage through the glacier, and for the potential occurrence of glacial lake outburst floods (GLOFs) if the lake overflows or the dam is breached.

GLOFs can be a major hazard in regions such as the Andes and Himalaya, and can result in fatalities as well as the destruction of land and infrastructure (Richardson and Reynolds, 2000; Rounce et al., 2016). GLOFs can either occur through a breach of the dam or by dam failure. Dam breach can be triggered by the increase of lake water-level and/or the creation of waves through: 
The Cryosphere Discuss., https://doi.org/10.5194/tc-2017-210

Manuscript under review for journal The Cryosphere

Discussion started: 2 November 2017

(c) Author(s) 2017. CC BY 4.0 License.

the addition of water from a lake higher up on the glacier (Buchroithner et al., 1982); an ice avalanche (Vuichard and Zimmermann, 1987); a rock avalanche or mass movement entering the lake (Harrison et al., 2006; Rounce et al., 2017); glacier calving (Kattelmann, 2003); rainfall events, particularly during the monsoon (Kattelmann, 2003; Osti et al., 2011); or an earthquake-triggered overtopping (Rounce et al. 2016).

The second mechanism by which a GLOF can occur is through dam failure, of either an icecored or a sediment-cored moraine. Ice-cored moraine dams are inferred to be common features at DCG proglacial lakes, as dead ice can be left beyond the glacier terminus as a result of both glacier retreat and differential mass wasting (Richardson and Reynolds, 2000). Ice-cored moraines degrade progressively by ablation beneath the debris layer and from the warmer lake water; this accelerates once the ice is exposed and subjected to enhanced aerial melt, and the dam may finally fail when water routes through relict glacial drainage features, such as voids, reducing the dam's structural strength (Kattelmann, 2003; Richardson and Reynolds, 2000). Non-ice-cored moraines are entirely composed of glacial sediment, and have been observed to destabilise and fail as a landslide after rainfall or earthquake events (Osti et al. 2011). Waves generated by the dam breach mechanism can also initiate rapid erosion of either type of moraine (Hubbard et al., 2005), possibly eventually triggering moraine failure (Kattelmann, 2003).

The onset of DCG recession by rapid calving could allow major rock and debris avalanches into a proglacial lake, which could trigger a GLOF and potentially destabilise a mountainside, with the possibility of further hazards such as landslides and rockfalls (Hubbard et al., 2005; Kirkbride and Warren, 1999). Risks from GLOFs can be mitigated, for example, by artificially lowering the proglacial lake water-level (Rana et al., 2000), or monitored using on-site or remotely sensed data (Bajracharya and Mool, 2009; Bolch et al., 2008; Nie et al., 2013; Rounce et al., 2016; Watson et al., 2015). As an increasing number of receding glaciers form a proglacial lake that not only withholds proglacial discharge, but dams it up against a potentially unstable moraine-dam, the possibility of devastating GLOFs could rise (Carrivick and Tweed, 2013; Gardelle et al., 2011; Stokes et al., 2007; Thompson et al., 2012).

\subsection{Proglacial streams}

Proglacial runoff from DCGs can form a significant proportion of the discharge of large rivers downstream, particularly in High Mountain Asia: the Indus, Dudh Koshi, Ganges and Brahmaputra rivers all stem from glacial meltwaters (Pritchard, 2017; Ragettli et al., 2015; Wilson et al., 2016). Proglacial discharge measurements, estimates and models have been made across the Himalaya, for example on individual glaciers in Nepal (Braun et al., 1993; Fujita and Sakai, 2014; Ragettli et al., 2015; Rana et al., 1997; Savéan et al., 2015; Soncini et al., 2016; Tangborn and Rana, 2000), Tibet (Kehrwald et al., 2008), the Tien Shan (Caiping and Yongjian, 2009; Han et al., 2010; Sorg et al., 2012), India (Hasnain, 1996, 1999; Khan et al., 2017; Singh et al., 1995, 2005; Singh and Bengtsson, 2004; Thayyen and Gergan, 2010), and for multiple catchments and entire regions (Winiger et al., 2005). However, few of these measurements have been made for longer than a decade: of the studies listed above, five measure discharge for a year or less; three have 2-3 years of measurements; and only one has 6 years of measurements; the rest use modelling to obtain estimates of proglacial discharge. Although Pritchard (2017) found that the glacial contribution to 
The Cryosphere Discuss., https://doi.org/10.5194/tc-2017-210

Manuscript under review for journal The Cryosphere

Discussion started: 2 November 2017

(c) Author(s) 2017. CC BY 4.0 License.

seven river basins in the Himalaya is proportionally small (0.1-3.0\%) it increases upstream and was argued to be vital to support the freshwater needs of millions of people.

The presence of surface debris can have a notable effect on the proglacial discharge of a DCG, resulting in a proglacial hydrograph that is different from that of a clean-ice glacier (Figure 9). For example, discharge both diurnally and through the ablation season are muted at debriscovered Dome Glacier, Canadian Rockies, compared to neighbouring clean-ice Athabasca Glacier (Figure 9), producing an annual variance in volumetric discharge of $1 \%$ compared to $24 \%$ respectively (Mattson, 2000). This is due in part to the suppression of surface melt by a debris cover, and in part to the lags that are induced as a result of the debris layer. On a clean-ice glacier, the maximum melt rate occurs close to the time of maximum incoming solar radiation. Conversely, on a DCG, the additional time to conduct heat through a debris layer and the warmer local air temperatures due to the warming debris introduces a delay. Thus, peak melt can occur up to several hours after the maximum radiation receipt at the debris surface (Carenzo et al., 2016; Conway and Rasmussen, 2000; Evatt et al., 2015), and has been measured occurring up to 24 hours later for debris layers $>0.85 \mathrm{~m}$ thick (Fyffe et al., 2014). This lag in diurnal peak melt is thus reflected in the timing of peak stream flow, producing a later and less pronounced peak in a proglacial stream's diurnal pattern (Fyffe et al., 2014).

Lags in the proglacial discharge at DCGs are also caused by the temporary storage of water within the debris layer. This has been observed during rainfall events and has been suggested to influence discharge through both the subglacial and proglacial drainage networks by delaying and buffering water transfer at the surface, potentially affecting basal water pressures and minimising peaks in proglacial discharge (Brock et al., 2010). However, in the Himalaya, the monsoon precipitation is thought to exert only a weak control on the proglacial discharge hydrograph of glaciers unless the intensity is $>\sim 20 \mathrm{~mm} \mathrm{~d}^{-1}$, which occurred on $20 \%$ of rainfall days during four years of monsoon measurements (Thayyen et al., 2005). Early in the melt season, meltwater is additionally stored within the snowpack of DCGs as well as within the debris layer year-round, providing a further delay in the transport of meltwater from the surface into the subsurface drainage system (Singh et al., 2006b). However, in the last two decades the amount of snowfall accumulation has decreased across the Himalaya, and is projected to decrease a further $20-40 \%$ by 2100 (Salerno et al., 2015; Viste and Sorteberg, 2015) which is highly likely to reduce this buffer and influence the proglacial hydrograph pattern of DCGs in the future.

Groundwater storage within glacial catchments has been inferred to interact with proglacial (and subglacial) stream networks, affecting the discharge patterns of the streams due to additional water storage and subsequent release (Gremaud et al., 2009; Smart, 1988, 1996). Andermann et al. (2012a) observed a lag between precipitation and discharge for 12 Himalayan catchments (both glacierised and non-glacierised), indicating that up to two-thirds of the river discharge is stored for approximately 45 days in a groundwater aquifer system before the monsoon, greatly affecting the annual discharge pattern. This has been recorded in further studies measuring SSC, with much lower concentrations measured post-monsoon once this groundwater begins to be released and reduces the SSC of these rivers (Andermann et al., 2012b; Andermann et al., 2012c). Such a significant effect of groundwater storage and release downriver from DCG catchments would suggest that similar processes may occur beneath the glaciers themselves. 
The Cryosphere Discuss., https://doi.org/10.5194/tc-2017-210

Manuscript under review for journal The Cryosphere

Discussion started: 2 November 2017

(c) Author(s) 2017. CC BY 4.0 License.

Other studies of glacierised limestone karst aquifers have used dye-tracing and modelling to investigate links to the glacial drainage system. At Glacier de la Plaine Morte, Swiss Alps, this showed that a greater proportion of the glacial meltwater was transported through a karst system during the winter; in the summer, the karst capacity was exceeded and the excess water drained through the glacier instead (Finger et al., 2013). A similar system in the Jade Dragon Snow Mountain region of southwest China was studied for stable isotopes and modelled by Zeng et al. (2015), showing that $29 \%$ of the glacier meltwater was transported into the karst aquifer. Groundwater sinks of subglacial meltwater can therefore comprise a significant portion of the total glacial output, potentially resulting in the glacial ablation being underestimated if this is not taken into account.

As DCGs provide a significant source of water for large populations, quantifying future runoff volumes is vital for planning and mitigating water resource issues. Models have been used to predict future runoff from DCGs for a single glacier basin (Ragettli et al., 2015; Singh et al., 2006a, 2008; Zhang et al., 2007), and multiple glacier basins (Immerzeel et al., 2012; Lowe and Collins, 2001) up to a regional scale (Rees and Collins, 2006; Shea and Immerzeel, 2016), investigating various future climatic scenarios. Currently, a large proportion of DCGs worldwide, particularly in the Himalaya, have negative mass balances (Bolch et al., 2011, 2012; Kääb et al., 2012; Scherler et al., 2011). The projected decrease in snowfall will additionally contribute to the decreasing mass of these glaciers, both by reducing accumulation rates but also by exposing the glacier surface to atmospheric melting earlier in the melt season (Salerno et al., 2015). Glacier contributions to catchment discharge in many regions have been predicted to increase over the next few decades, but as the glaciers continue to shrink, this proportion will begin to reduce substantially due to the significantly smaller volume of glaciers remaining (Barnett et al., 2005; Bolch, 2017; Bolch et al., 2012; Huss, 2011; Lutz et al., 2014). Shea \& Immerzeel (2016) estimated that most basins will have declining glacier contributions to streamflow by 2100 , and water shortage may then be a concern for many populated areas in the Karakoram, while peak flows may represent a greater concern in the eastern Himalaya.

A further concern for future water supplies is the water quality provided by glacial discharge, which is commonly assessed through measurements of the EC and SSC of proglacial streams. Although based on simplified mixing models, studies have used proglacial stream SSC to calculate the contribution of glacial systems to overall catchment sediment yields (Collins 1996; Collins 1999; Hasnain \& Thayyen 1999a; Singh et al. 2005; Haritashya et al. 2010). For example, Collins (1996) determined from investigations at Batura Glacier, Karakoram Himalaya, that $40 \%$ of the sediment yield of the Indus river, and $60 \%$ of the Hunza river are glacially-derived. Tectonic uplift also contributes through enhanced weathering to the high sediment flux in these regions (Collins, 1996). However, the glacially-derived proportion of total sediment yield can vary widely with, in general, glaciers with more extensive subglacial systems and higher discharges contributing greater amounts of sediment (Collins, 1999). Proglacial SSC therefore increases with discharge during the ablation season, particularly with monsoon rainfall (Collins 1999; Hasnain \& Thayyen 1999a) when supraglacial debris weathering is enhanced and the increased discharge flushes sediment through the system, increasing chemical weathering rates (Hasnain \& Thayyen 1999b; Hodson et al. 2002) which may have implications on the water quality downstream as discharge increases with glacier mass loss. Although the monsoon rains contribute to enhanced 
The Cryosphere Discuss., https://doi.org/10.5194/tc-2017-210

Manuscript under review for journal The Cryosphere

Discussion started: 2 November 2017

(c) Author(s) 2017. CC BY 4.0 License.

sediment transport, they are not considered to affect weathering within the subglacial systems of such glaciers, where sulphide oxidation and calcium carbonate dissolution dominate (Tranter et al., 2002). On a diurnal scale, Kumar et al. (2009) found that the total ion concentration of proglacial meltwater increased from the afternoon onwards, as the (inferred) englacial and subglacial systems of Gangotri Glacier, became more active.

The water quality of proglacial runoff, including carbon export and other nutrient delivery from glacial basins, exerts a critical influence on biogeochemical fluxes, ecosystem services, downstream ecology and aquatic ecosystem biodiversity (Jacobsen et al., 2012). Ecological responses are extremely sensitive to reductions in glacier area, with studies finding that freshwater biodiversity in glacier-fed streams will decrease rapidly with the reduction (and ultimate disappearance) of glacier area (Cauvy-Fraunié et al., 2016; Jacobsen et al., 2012; Milner et al., 2009; Wilhelm et al., 2013). The potential loss of species is a key issue for future conservation and the evolution of glaciers, particularly DCG, will have a large influence on any loss of species (Jacobsen et al., 2012), an area of study largely beyond the remit of this review, but which deserves further investigation.

\section{Summary and future research priorities}

The hydrology of DCGs is sufficiently distinctive to warrant bespoke treatment, separate from that of clean-ice valley glaciers. This distinctiveness stems principally from the extensive and thick debris cover on DCGs as well as, in many cases, their high elevation and local climate (such as the South Asian monsoon) affecting the mass balance. These factors combine to produce a reverse ablation gradient, where the point of maximum melt is located several kilometres up-glacier from the terminus. In times of recession, a low angle, or even reversed, longitudinal surface profile develops that is hummocky, promoting the surface storage of water in steep-sided supraglacial ponds. These ponds serve to attenuate flows and regulate the outlet hydrograph. Additionally, in contrast to their clean-ice counterparts, DCGs convey at least some of their surface water at the ice-debris interface, likely as a thin film, and the debris layer itself can provide temporary water storage that delays peak flow at the terminus.

Englacially, channels are likely formed through downcutting and/or the exploitation of structural weaknesses, and the surface debris layer probably plays an important role in determining the thermal characteristics of the upper part of the ice column. Subglacially, little is known, but inferences point to the likely presence of water through the observation of seasonal velocity speed-ups and bulk meltwater analysis. At the terminus, recent recession has resulted in the development of moraine-impounded lakes, which are increasing in both number and size in many areas of the world (Gardelle et al., 2011). Downstream, many millions of people rely on glacially-sourced water for irrigation, power and sanitation, but a key gap remains in determining the importance (in terms of quantity and quality) of meltwater as opposed to groundwater and precipitation with increasing distance from the glacier terminus.

Despite the importance of glacially-sourced meltwater for many populations around the world, knowledge of the hydrology of DCGs lags behind that of their clean-ice counterparts. In particular, the subsurface hydrology of DCGs remains largely un-investigated and poorly understood. Similarly, key parameters governing the formation and structure of these systems, 
The Cryosphere Discuss., https://doi.org/10.5194/tc-2017-210

Manuscript under review for journal The Cryosphere

Discussion started: 2 November 2017

(c) Author(s) 2017. CC BY 4.0 License.

particularly thermal regime and basal conditions, are also largely unknown at DCGs. On the basis of the above review, we summarise the current status of our understanding of the hydrology of DCGs as a schematic illustration in Figure 10.

Inspection of Figure 10 reveals eight candidate areas for future hydrological research, considered below:

1. Water flow through and beneath the supraglacial debris layer. Currently, there has been minimal research into debris layer hydrology, whether it be a focus on water movement, water storage, water chemistry, links to other parts of the glacier hydrological system, or the removal of meltwater from the system through evaporation from the debris layer. Not only is this important for considering potential delays within the drainage system due to water storage and the impact upon thermal properties of the debris layer due to the role moisture holds in dictating thermal conductivity, but it could also have an effect on water quality downstream. It was noted in Section 5 that water flowing through debris or sediment, particularly at the bed, entrains greater concentrations of solutes and SSC. With flowpaths through debris at the surface increasing in extent as both the debris cover continues to increase upglacier (Kirkbride and Warren, 1999; Stokes et al., 2007) and meltwater production increases with warming temperatures, these solute levels could be expected to be raised further, affecting proglacial water quality. Furthermore, the hydrology of the sub-debris layer ice surface is likely to exert an important influence on ablation, and thus the production of meltwater.

2. Supraglacial pond hydrology. Although substantial recent effort has been directed to the study of supraglacial ponds and lakes at DCGs, the flow of water within these features, and between them and other parts of the hydrological system, remains poorly understood, as does their biogeochemistry (Bhatt et al., 2007; Takeuchi et al., 2012). Meltwater is stored within supraglacial ponds and lakes - and as more, larger lakes form with greater future meltwater production - this could delay outflow regimes both diurnally and seasonally. How water is transported out of a lake is also poorly understood: are there supraglacial or englacial links between ponds; if they are englacial, is all of this water transported to the next pond or is some routed deeper into the glacier? As a result, this could influence the development of englacial and subglacial drainage networks by altering the amount of water that is, or can be, transported within the glacier.

3. DCG thermal regime. An almost complete lack of knowledge of the thermal regime of highelevation DCGs has resulted in a critically poor understanding of the existence and character of englacial and subglacial drainage systems. If water cannot drain into such glaciers it is unlikely that an englacial system can exist at all. Yet, it is unknown whether englacial systems are entirely limited by the thermal regime of the ice.

4. DCG englacial drainage. Despite detailed glaciospeleological investigations, access has limited these to large, open channels in accessible areas. Hence, little is known about active englacial hydrology or smaller englacial hydrological pathways deeper within DCGs, or how meltwater is transported from the supraglacial system into the glacier. The small scale (microporous) movement of water between ice crystals has also received very little attention and may form an important meltwater flowpath, for example through rotted surface ice. At the larger scale, englacial drainage appears to be governed by base-levels, 
The Cryosphere Discuss., https://doi.org/10.5194/tc-2017-210

Manuscript under review for journal The Cryosphere

Discussion started: 2 November 2017

(c) Author(s) 2017. CC BY 4.0 License.

but controls over such levels and flow pathway configurations are poorly understood (they could be local or dictated by proglacial lake level), while englacial drainage below such levels (i.e. within the phreatic zone) remains un-investigated.

5. DCG subglacial drainage. Perhaps the greatest hydrological unknown of DCGs is that of the existence and character of subglacial drainage, which is critical to governing both ice motion and meltwater quality. Several indirect studies have suggested the existence of such effects, but no definitive evidence has yet been reported. If the presence of subglacial drainage is reported at high-elevation DCGs, then exploring the character and spatiotemporal variability of such drainage represents a key research priority.

6. Groundwater flows. While water loss from DCGs has been inferred, no study has yet reported on the mechanisms and rates of water transfer between a DCG's drainage system and that of the underlying substrate. It is therefore important to understand the proportion of river discharge that is provided by glacier meltwater and runoff, and how much is being stored within or immediately beyond the glacial drainage network at different time scales.

7. Long-term water delivery from DCGs. Long term records of proglacial discharge from DCGs are scarce, being limited to less than a decade of measurements for a small number of Himalayan DCGs. As DCGs are predicted to ablate more rapidly with the formation and growth of more supraglacial ponds and ice cliffs, discharge has been projected to increase in the short-term but decrease in the long-term, creating concerns for future water availability in many regions. A greater understanding of how DCGs are and will respond to the current and future warming climate would constrain future proglacial discharge volumes and thus help to mitigate water resource issues and other hazards such as potentially unstable moraine-dammed proglacial lakes.

8. Local climate influence on DCG hydrology. Regionally, the local climate is highly likely to have a substantial influence on the hydrological systems of DCGs, for example, monsoonrelated weather. However, largely due to the inclement weather associated with monsoon precipitation at high elevations, the hydrological influence of the monsoon has not yet been addressed. Research to understand the role of monsoon conditions, and its relationship to non-monsoon conditions, is therefore required.

\section{Author contribution}

$\mathrm{KM}$ and $\mathrm{BH}$ planned the manuscript. $\mathrm{KM}$ led the manuscript writing and illustration with all coauthors contributing to specific sections.

\section{Competing interests}

The authors declare that they have no conflict of interest.

\section{Acknowledgements}

This research was supported by the 'EverDrill' Natural Environment Research Council Grant awarded to Aberystwyth University (NE/P002021) and the University of Leeds (NE/P00265X). KM is funded by an AberDoc PhD Studentship. The authors thank C. Scott Watson (University of Leeds) for providing the RapidEye image used in Figure 1, and Antony Smith (Aberystwyth University) for 
The Cryosphere Discuss., https://doi.org/10.5194/tc-2017-210

Manuscript under review for journal The Cryosphere

Discussion started: 2 November 2017

(c) Author(s) 2017. CC BY 4.0 License.

redrawing Figure 9 and illustrating Figure 10. They are also grateful to Himalayan Research Expeditions for organising the logistics that supported fieldwork in Nepal during 2017, and in particular Mahesh Magar for guiding and navigation.

\section{References}

Academica Sinica: Basic features of the glaciers of Mt. Jolmo Lungma Region, Southern part of the Tibet Autonomous Region, China, Sci. Sin., 18(1), 106-130, 1975.

Adhikary, S., Nakawo, M., Seko, K. and Shakya, B.: Dust influence on the melting process of glacier ice: experimental results from Lirung Glacier, Nepal Himalayas, in Debris-Covered Glaciers, edited by M. Nakawo, C. F. Raymond, and A. Fountain, pp. 43-52, International Association of Hydrological Sciences, Oxford. [online] Available from: http://books.google.com/books?hl=en\&lr=\&id=ghn8LV2CZ20C\&oi=fnd\&pg=PA43\&dq=Dust+influence +on+the+melting+process+of+glacier+ice\&ots=RssBAePMH3\&sig=EPkFJdTtWOJ3F8fWog5LKpCJ3OY\%5 Cnpapers2://publication/uuid/14FFD620-FE05-4094-92DE-FCD92BF61E6E, 2000.

Ageta, Y., Iwata, S., Yabuki, H., Naito, N., Sakai, A., Narama, C. and Karma: Expansion of glacier lakes in recent decades in the Bhutan Himalayas, in Debris-Covered Glaciers, vol. 264, edited by M. Nakawo, C. F. Raymond, and A. Fountain, pp. 165-175, International Association of Hydrological Sciences, Oxford., 2000.

Andermann, C., Crave, A., Gloaguen, R., Davy, P. and Bonnet, S.: Connecting source and transport: Suspended sediments in the Nepal Himalayas, Earth Planet. Sci. Lett., 351-352, 158-170, doi:10.1016/j.epsl.2012.06.059, 2012a.

Andermann, C., Longuevergne, L., Bonnet, S., Crave, A., Davy, P. and Gloaguen, R.: Impact of transient groundwater storage on the discharge of Himalayan rivers, Nat. Geosci., 5(2), 127-132, doi:10.1038/ngeo1356, 2012b.

Andermann, C., Bonnet, S., Crave, A., Davy, P., Longuevergne, L. and Gloaguen, R.: Sediment transfer and the hydrological cycle of Himalayan rivers in Nepal, Comptes Rendus Geosci., 344(11-12), 627-635, doi:10.1016/j.crte.2012.10.009, 2012c.

Anderson, L. S. and Anderson, R. S.: Modeling debris-covered glaciers: Response to steady debris deposition, Cryosph., 10(3), 1105-1124, doi:10.5194/tc-10-1105-2016, 2016.

Anderson, R.: A model of ablation-dominated medial moraines and the generation of debris-mantled glacier snouts, J. Glaciol., 46(154), 459-469, 2000.

Bajracharya, S. R. and Mool, P.: Glaciers, glacial lakes and glacial lake outburst floods in the Mount Everest region, Nepal, Ann. Glaciol., 50(53), 81-86, doi:10.3189/172756410790595895, 2009.

Baker, V. R.: Water and the martian landscape, Nature, 412(6843), 228-236, doi:10.1038/35084172, 2001.

Barnett, T. P., Adam, J. C. and Lettenmaier, D. P.: Potential impacts of a warming climate on water availability in snow-dominated regions, Nature, 438(7066), 303-309, doi:10.1038/nature04141, 2005.

Bartholomaus, T. C., Anderson, R. S. and Anderson, S. P.: Response of glacier basal motion to transient water storage, Nat. Geosci., 1(1), 33-37, doi:10.1038/ngeo.2007.52, 2008.

Bartholomaus, T. C., Anderson, R. S. and Anderson, S. P.: Growth and collapse of the distributed subglacial hydrologic system of Kennicott Glacier, Alaska, USA, and its effects on basal motion, J. Glaciol., 57(206), 985-1002, doi:10.3189/002214311798843269, 2011.

Benn, D., Gulley, J., Luckman, A., Adamek, A. and Glowacki, P. S.: Englacial drainage systems formed by 
The Cryosphere Discuss., https://doi.org/10.5194/tc-2017-210

Manuscript under review for journal The Cryosphere

Discussion started: 2 November 2017

(c) Author(s) 2017. CC BY 4.0 License.

hydrologically driven crevasse propagation, J. Glaciol., 55(191), 513-523, doi:10.3189/002214309788816669, 2009.

Benn, D. I., Wiseman, S. and Warren, C. R.: Rapid growth of a supraglacial lake, Ngozumpa Glacier, Khumbu Himal, Nepal, IAHS Publ., 264(2), 177-185, 2000.

Benn, D. I., Wiseman, S. and Hands, K. A.: Growth and drainage of supraglacial lakes on debris-mantled Ngozumpa Glacier, Khumbu Himal, Nepal, J. Glaciol., 47(159), 626-638, doi:10.3189/172756501781831729, 2001.

Benn, D. I., Bolch, T., Hands, K., Gulley, J., Luckman, A., Nicholson, L. I., Quincey, D., Thompson, S., Toumi, R. and Wiseman, S.: Response of debris-covered glaciers in the Mount Everest region to recent warming, and implications for outburst flood hazards, Earth-Science Rev., 114(1-2), 156-174, doi:10.1016/j.earscirev.2012.03.008, 2012.

Benn, D. I., Thompson, S., Gulley, J., Mertes, J., Luckman, A. and Nicholson, L.: Structure and evolution of the drainage system of a Himalayan debris-covered glacier, and its relationship with patterns of mass loss, Cryosph. Discuss., (March), 1-43, doi:10.5194/tc-2017-29, 2017.

Bhatt, M. P., Masuzawa, T., Yamamoto, M. and Takeuchi, N.: Chemical characteristics of pond waters within the debris area of Lirung Glacier in Nepal Himalaya, J. Limnol., 66(2), 71-80, 2007.

Blatter, H. and Hutter, K.: Polythermal conditions in Arctic glaciers, J. Glaciol., 37(126), 261-269, doi:http://adsabs.harvard.edu/abs/1990JGlac..37..261B, 1991.

Bocchiola, D., Senese, A., Mihalcea, C., Mosconi, B., D’Agata, C., Smiraglia, C. and Diolaiuti, G.: An ablation model for debris-covered ice: The case study of Venerocolo glacier (Italian Alps), Geogr. Fis. e Din. Quat., 38(2), 113-128, doi:10.4461/GFDQ.2015.38.11, 2015.

Bolch, T.: Hydrology: Asian glaciers are a reliable water source, Nature, 545(7653), 161-162, doi:10.1038/545161a, 2017.

Bolch, T., Buchroithner, M. F., Peters, J., Baessler, M. and Bajracharya, S.: Identification of glacier motion and potentially dangerous glacial lakes in the Mt. Everest region/Nepal using spaceborne imagery, Nat. Hazards Earth Syst. Sci., 8(6), 1329-1340, doi:10.5194/nhess-8-1329-2008, 2008.

Bolch, T., Pieczonka, T. and Benn, D. I.: Multi-decadal mass loss of glaciers in the Everest area (Nepal Himalaya) derived from stereo imagery, Cryosph., 5(2), 349-358, doi:10.5194/tc-5-349-2011, 2011.

Bolch, T., Kulkarni, a., Kaab, a., Huggel, C., Paul, F., Cogley, J. G., Frey, H., Kargel, J. S., Fujita, K., Scheel, M., Bajracharya, S. and Stoffel, M.: The State and Fate of Himalayan Glaciers, Science (80-. )., 336(6079), 310-314, doi:10.1126/science.1215828, 2012.

Boulton, G. S. and Hindmarsh, R. C. A.: Sediment deformation beneath glaciers: rheology and geological consequences, J. Geophys. Res., 92(B9), 9059--9082, 1987.

Braun, L. N., Grabs, W. and Rana, B.: Application of a Conceptual Precipitation- Runoff Model in the Langtang Khola Basin, Nepal Himalaya, Snow Glacier Hydrol. (Proceedings Kathmandu Symp. Novemb. 1992). IAHS Publ. no. 218,1993., 218(218), 221-237, 1993.

Brock, B. W., Mihalcea, C., Kirkbride, M. P., Diolaiuti, G., Cutler, M. E. J. and Smiraglia, C.: Meteorology and surface energy fluxes in the 2005-2007 ablation seasons at the Miage debris-covered glacier, Mont Blanc Massif, Italian Alps, J. Geophys. Res. Atmos., 115(9), 1-16, doi:10.1029/2009JD013224, 2010.

Brun, F., Buri, P., Miles, E. S., Wagnon, P., Steiner, J., Berthier, E., Ragettli, S., Kraaijenbrink, P., Immerzeel, W. W. and Pellicciotti, F.: Quantifying volume loss from ice cliffs on debris-covered glaciers using highresolution terrestrial and aerial photogrammetry, J. Glaciol., 62(234), 684-695, doi:10.1017/jog.2016.54, 2016. 
The Cryosphere Discuss., https://doi.org/10.5194/tc-2017-210

Manuscript under review for journal The Cryosphere

Discussion started: 2 November 2017

(c) Author(s) 2017. CC BY 4.0 License.

1035

1036

1037

1038

1039

1040

1041

1042

1043

1044

1045

1046

1047

1048

1049

1050

1051

1052

1053

1054

1055

1056

1057

1058

1059

1060

1061

1062

1063

1064

1065

1066

1067

1068

1069

1070

1071

1072

1073

1074

1075

1076

1077
Buchroithner, M. F., Jentsch, G. and Wanivenhaus, B.: Monitoring of Recent Geological Events in the Khumbu Area (Himalaya, Nepal) by Digital Processing of Landsat MSS Data, Rock Mech., 15, 181-197, 1982.

Buri, P., Pellicciotti, F., Steiner, J. F., Miles, E. S. and Immerzeel, W. W.: A grid-based model of backwasting of supraglacial ice cliffs on debris-covered glaciers, Ann. Glaciol., 57(71), 199-211, doi:10.3189/2016AoG71A059, 2016a.

Buri, P., Miles, E. S., Steiner, J. F., Immerzeel, W. W., Wagnon, P. and Pellicciotti, F.: A physically-based 3-D model of ice cliff evolution on a debris-covered glacier, J. Geophys. Res. Earth Surf., 121, 2471-2493, doi:10.1002/2016JF004039, 2016b.

Caiping, C. and Yongjian, D.: The application of artificial neural networks to simulate meltwater runoff of Keqikaer Glacier, south slope of Mt. Tuomuer, western China, Environ. Geol., 57(8), 1839-1845, doi:10.1007/s00254-008-1471-1, 2009.

Carenzo, M., Pellicciotti, F., Mabillard, J., Reid, T. and Brock, B. W.: An enhanced temperature index model for debris-covered glaciers accounting for thickness effect, Adv. Water Resour., 94, 457-469, doi:10.1016/j.advwatres.2016.05.001, 2016.

Carrivick, J. L. and Tweed, F. S.: Proglacial Lakes: Character, behaviour and geological importance, Quat. Sci. Rev., 78, 34-52, doi:10.1016/j.quascirev.2013.07.028, 2013.

Casey, K. A., Kääb, A. and Benn, D. I.: Geochemical characterization of supraglacial debris via in situ and optical remote sensing methods: a case study in Khumbu Himalaya, Nepal, Cryosph., 6(1), 85-100, doi:10.5194/tc-6-85-2012, 2012.

Cauvy-Fraunié, S., Andino, P., Espinosa, R., Calvez, R., Jacobsen, D. and Dangles, O.: Ecological responses to experimental glacier-runoff reduction in alpine rivers, Nat. Commun., 7(May), 12025, doi:10.1038/ncomms12025, 2016.

Chaturvedi, R. K., Kulkarni, A., Karyakarte, Y., Joshi, J. and Bala, G.: Glacial mass balance changes in the Karakoram and Himalaya based on CMIP5 multi-model climate projections, Clim. Change, 123(2), 315328, doi:10.1007/s10584-013-1052-5, 2014.

Chikita, K., Jha, J. and Yamada, T.: The basin expansion mechanism of a supraglacial lake in the Nepal Himalaya, J. Hokkaido Univ. Fac. Sci. Ser. VII Geophys., 11(2), 501-521, 1998.

Chikita, K., Jha, J. and Yamada, T.: Sedimentary effects on the expansion of a Himalayan supraglacial lake, Glob. Planet. Change, 28(1-2), 23-34, doi:10.1016/S0921-8181(00)00062-X, 2001.

Chinn, T. J. H. and Dillon, A.: Observation on a debris-covered polar glacier "Whisky Glacier", James Ross Island, Antarctic Peninsula, Antarctica, J. Glaciol., 33(115), 300-310 [online] Available from: https://www.researchgate.net/publication/258964567_Observation_on_a_debriscovered_polar_glacier_'Whisky_Glacier'_James_Ross_Island_Antarctic_Peninsula_Antarctica, 1987.

Chu, V. W.: Greenland ice sheet hydrology: A review, Prog. Phys. Geogr., 38(1), 19-54, doi:10.1177/0309133313507075, 2014.

Clark, D., Clark, M. and Gillespie, A.: Debris-covered glaciers in the Sierra Nevada, California, and their implications for snowline reconstructions, Quat. Res., 41, 139-153, 1994.

Collier, E., Nicholson, L. I., Brock, B. W., Maussion, F., Essery, R. and Bush, A. B. G.: Representing moisture fluxes and phase changes in glacier debris cover using a reservoir approach, Cryosph., 8, 1429-1444, doi:10.5194/tc-8-1429-2014, 2014.

Collier, E., Maussion, F., Nicholson, L., Mölg, T., Immerzeel, W. and Bush, A.: Impact of debris cover on glacier ablation and atmosphere-glacier feedbacks in the Karakoram, Cryosph., 9, 1617-1632, 
The Cryosphere Discuss., https://doi.org/10.5194/tc-2017-210

Manuscript under review for journal The Cryosphere

Discussion started: 2 November 2017

(c) Author(s) 2017. CC BY 4.0 License.

doi:10.5194/tc-9-1617-2015, 2015.

1079

1080

1081

1082

1083

1084

1085

1086

1087

1088

1089

1090

1091

1092

1093

1094

1095

1096

1097

1098

1099

1100

1101

1102

1103

1104

1105

1106

1107

1108

1109

1110

1111

1112

1113

1114

1115

1116

1117

1118

1119

1120
Collins, D. N.: Sediment transport from glacierized basins in the Karakoram Mountains, IAHS Publ. Proc. Exet. Symp. July 1996, (236), 85-96 [online] Available from: http://books.google.com/books?hl=en\&amp;Ir=\&amp;id=bZufVQV5yAC\&amp;oi=fnd\&amp;pg=PA85\&amp;dq=Sediment+transport+from+glacierized+basins+in+th e+Karakoram+mountains\&amp;ots=u_RhK-Cx1T\&amp;sig=mPSIDAxp6cTfdAH3zojJEXj576Y, 1996.

Collins, D. N.: Solute flux in meltwaters draining from a glacierized basin in the Karakoram mountains, Hydrol. Process., 13(18), 3001-3015, doi:10.1002/(SICI)1099-1085(19991230)13:18<3001::AIDHYP15>3.0.CO;2-N, 1999.

Conway, H. and Rasmussen, L. A.: Summer temperature profiles within supraglacial debris on Khumbu Glacier, Nepal, in Debris-Covered Glaciers, edited by M. Nakawo, C. F. Raymond, and A. Fountain, pp. 89-97, International Association of Hydrological Sciences, Oxford., 2000.

Copland, L., Pope, S., Bishop, M. P., Shroder, J. F., Clendon, P., Bush, a. B. G., Kamp, U., Seong, Y. B. and Owen, L. a.: Glacier velocities across the Karakoram Himalaya, Ann. Glaciol., 50(52), 1-18, doi:10.3189/172756409789624229, 2009.

Dunning, S. A., Rosser, N. J., Mccoll, S. T. and Reznichenko, N. V: Rapid sequestration of rock avalanche deposits within glaciers, Nat. Commun., 6(7964), 1-7, doi:10.1038/ncomms8964, 2015.

Emmer, A., Loarte, E. C., Klimeš, J. and Vilímek, V.: Recent evolution and degradation of the bent Jatunraju glacier (Cordillera Blanca, Peru), Geomorphology, 228, 345-355, doi:10.1016/j.geomorph.2014.09.018, 2015.

Eriksson, M., Jianchu, X., Shrestha, A., Vaidya, R., Nepal, S. and Sandström, K.: The Changing Himalayas: Impact of climate change on water resources and livelihoods in the greater Himalayas, Int. Cent. Integr. Mt. Dev., 114, 1-28, doi:10.1144/SP312.3, 2009.

Etzelmüller, E., Ødegård, R., Vatne, G., Mysterud, R., Tonning, T. and Sollid, J.: Glacier characteristics and sediment transfer system of Longyearbreen and Larsbreen, western Spitsbergen, Nor. Geogr. Tidsskr. Nor. J. Geogr., 54(4), 157-168, 2001.

Evatt, G. W., Abrahams, I. D., Heil, M., Mayer, C., Kingslake, J., Mitchell, S. L., Fowler, A. C. and Clark, C. D.: Glacial melt under a porous debris layer, J. Glaciol., 61(229), 825-836, doi:10.3189/2015JoG14J235, 2015.

Finger, D., Hugentobler, A., Huss, M., Voinesco, A., Wernli, H., Fischer, D., Weber, E., Jeannin, P. Y., Kauzlaric, M., Wirz, A., Vennemann, T., Hüsler, F., Schädler, B. and Weingartner, R.: Identification of glacial meltwater runoff in a karstic environment and its implication for present and future water availability, Hydrol. Earth Syst. Sci., 17(8), 3261-3277, doi:10.5194/hess-17-3261-2013, 2013.

Foster, L. A., Brock, B. W., Cutler, M. E. J. and Diotri, F.: A physically based method for estimating supraglacial debris thickness from thermal band remote-sensing data, J. Glaciol., 58(210), 677-691, doi:10.3189/2012JoG11J194, 2012.

Fountain, A. G. and Walder, J. S.: Water flow through temperate glaciers, Rev. Geophys., 36(97), 299, doi:10.1029/97RG03579, 1998.

Fujita, K. and Sakai, A.: Modelling runoff from a Himalayan debris-covered glacier, Hydrol. Earth Syst. Sci., 18(7), 2679-2694, doi:10.5194/hess-18-2679-2014, 2014.

Fyffe, C. L., Reid, T. D., Brock, B. W., Kirkbride, M. P., Diolaiuti, G., Smiraglia, C. and Diotri, F.: A distributed energy-balance melt model of an alpine debris-covered glacier, J. Glaciol., 60(221), 587-602, doi:10.3189/2014JoG13J148, 2014. 
The Cryosphere Discuss., https://doi.org/10.5194/tc-2017-210

Manuscript under review for journal The Cryosphere

Discussion started: 2 November 2017

(c) Author(s) 2017. CC BY 4.0 License.

1131

1132

1133

1134

1135

1136

1137

1138

1139

1140

1141

1142

1143

1144

1145

1146

1147

1148

1149

1150

1151

1152

1153

1154

1155

1156

1157

1158

1159

1160

1161

1162

1163

Gades, A., Conway, H., Nereson, N., Naito, N. and Kadota, T.: Radio echo-sounding through supraglacial debris on Lirung and Khumbu Glaciers, Nepal Himalayas, in Debris-Covered Glaciers, vol. 264, edited by M. Nakawo, C. F. Raymond, and A. Fountain, pp. 13-22, International Association of Hydrological Sciences, Oxford., 2000.

Gardelle, J., Arnaud, Y. and Berthier, E.: Contrasted evolution of glacial lakes along the Hindu Kush Himalaya mountain range between 1990 and 2009, Glob. Planet. Change, 75(1-2), 47-55, doi:10.1016/j.gloplacha.2010.10.003, 2011.

Gibson, M., Glasser, N., Quincey, D., Rowan, A. and Irvine-Fynn, T.: Changes in glacier surface cover on Baltoro glacier, Karakoram, north Pakistan, 2001-2012, J. Maps, 13(2), 100-108, doi:10.1080/17445647.2016.1264319, 2017a.

Gibson, M. J., Glasser, N. F., Quincey, D. J., Mayer, C., Rowan, A. V. and Irvine-Fynn, T. D. L.: Temporal variations in supraglacial debris distribution on Baltoro Glacier, Karakoram between 2001 and 2012, Geomorphology, 295, 572-585, doi:10.1016/j.geomorph.2017.08.012, 2017b.

Glen, J.: The Creep of Polycrystalline Ice, Proc. R. Soc. A Math. Phys. Eng. Sci., 228(1175), 519-538, 1955.

Greenwood, S. L., Clason, C. C., Helanow, C. and Margold, M.: Theoretical, contemporary observational and palaeo-perspectives on ice sheet hydrology: Processes and products, Earth-Science Rev., 155, 1-27, doi:10.1016/j.earscirev.2016.01.010, 2016.

Gremaud, V., Goldscheider, N., Savoy, L., Favre, G. and Masson, H.: Geological structure, recharge processes and underground drainage of a glacierised karst aquifer system, Tsanfleuron-Sanetsch, Swiss Alps, Hydrogeol. J., 17(8), 1833-1848, doi:10.1007/s10040-009-0485-4, 2009.

Gruber, S. and Haeberli, W.: Permafrost in steep bedrock slopes and its temperatures-related destabilization following climate change, J. Geophys. Res. Earth Surf., 112(2), 1-10, doi:10.1029/2006JF000547, 2007.

Gruber, S., Hoelzle, M. and Haeberli, W.: Permafrost thaw and destabilization of Alpine rock walls in the hot summer of 2003, Geophys. Res. Lett., 31(13), 1-4, doi:10.1029/2004GL020051, 2004.

Gulley, J. and Benn, D. I.: Structural control of englacial drainage systems in Himalayan debris-covered glaciers, J. Glaciol., 53(182), 399-412, doi:10.3189/002214307783258378, 2007.

Gulley, J. D., Benn, D. I., Müller, D. and Luckman, A.: A cut-and-closure origin for englacial conduits in uncrevassed regions of polythermal glaciers, J. Glaciol., 55(189), 66-80, doi:10.3189/002214309788608930, 2009a.

Gulley, J. D., Benn, D. I., Screaton, E. and Martin, J.: Mechanisms of englacial conduit formation and their implications for subglacial recharge, Quat. Sci. Rev., 28(19-20), 1984-1999, doi:10.1016/j.quascirev.2009.04.002, 2009b.

Hambrey, M. J., Quincey, D. J., Glasser, N. F., Reynolds, J. M., Richardson, S. J. and Clemmens, S.: Sedimentological, geomorphological and dynamic context of debris-mantled glaciers, Mount Everest (Sagarmatha) region, Nepal, Quat. Sci. Rev., 28(11-12), 1084, doi:10.1016/j.quascirev.2009.04.009, 2008.

Han, H., Wang, J., Wei, J. and Liu, S.: Backwasting rate on debris-covered Koxkar glacier, Tuomuer mountain, China, J. Glaciol., 56(196), 287-296, doi:10.3189/002214310791968430, 2010.

Hannah, D. M., Kansakar, S. R., Gerrard, A. J. and Rees, G.: Flow regimes of Himalayan rivers of Nepal: Nature and spatial patterns, J. Hydrol., 308(1-4), 18-32, doi:10.1016/j.jhydrol.2004.10.018, 2005.

Haritashya, U. K., Kumar, A. and Singh, P.: Particle size characteristics of suspended sediment transported in meltwater from the Gangotri Glacier, central Himalaya - An indicator of subglacial sediment 
The Cryosphere Discuss., https://doi.org/10.5194/tc-2017-210

Manuscript under review for journal The Cryosphere

Discussion started: 2 November 2017

(c) Author(s) 2017. CC BY 4.0 License.

Harrison, S., Glasser, N., Winchester, V., Haresign, E., Warren, C. and Jansson, K.: A glacial lake outburst flood associated with recent mountain glacier retreat, Patagonian Andes, The Holocene, 16(4), 611-620, doi:10.1191/0959683606hl957rr, 2006.

1167

1168

1169

Hasnain, S. I.: Factors controlling suspended sediment transport in Himalayan glacier meltwaters, J. Hydrol., 181(1-4), 49-62, doi:10.1016/0022-1694(95)02917-6, 1996.

1170

1171

Hasnain, S. I.: Runoff characteristics of a glacierized catchment, Garhwal Himalaya, India, Hydrol. Sci. J., 44(6), 847-854, doi:10.1080/02626669909492284, 1999.

Hasnain, S. I. and Thayyen, R. J.: Hydrograph separation of bulk meltwaters of Dokriani Bamak glacier basin, based on electrical conductivity, Curr. Sci., 67(3), 189-193, 1994.

1174

1175

Hasnain, S. I. and Thayyen, R. J.: Controls on the major-ion chemistry of the Dokriani glacier meltwaters, Ganga basin, Garhwal Himalaya, India, J. Glaciol., 45(149), 87-92, 1999a.

1176

1177

Hasnain, S. I. and Thayyen, R. J.: Discharge and suspended-sediment concentration of meltwaters, draining from the Dokriani glacier, Garhwal Himalaya, India, J. Hydrol., 218(3-4), 191-198, doi:10.1016/S00221694(99)00033-5, 1999b.

1179

1180

1181

1182

1183

Hasnain, S. I., Jose, P. G., Ahmad, S. and Negi, D. C.: Character of the subglacial drainage system in the ablation area of Dokriani glacier, India, as revealed by dye-tracer studies, J. Hydrol., 248(1-4), 216-223, doi:10.1016/S0022-1694(01)00404-8, 2001.

Head, J. W. and Marchant, D. R.: Cold-based mountain glaciers on Mars: Western Arsia Mons, Geology, 31(7), 641-644, doi:10.1130/0091-7613(2003)031<0641:CMGOMW>2.0.CO;2, 2003.

1184

1185

Hewitt, K., Wake, C. P., Young, G. J. and David, C.: Hydrological investigations at Biafo Glacier, Karakoram range, Himalaya: an important source of water for the Indus River, Ann. Glaciol., 13, 103-108, 1989.

1186

Hewitt, K., Clague, J. J. and Orwin, J. F.: Legacies of catastrophic rock slope failures in mountain landscapes, Earth-Science Rev., 87(1-2), 1-38, doi:10.1016/j.earscirev.2007.10.002, 2008.

1188

1189

Hodson, A., Porter, P., Lowe, A. and Mumford, P.: Chemical denudation and silicate weathering in Himalayan glacier basins: Batura Glacier, Pakistan, J. Hydrol., 262(1-4), 193-208, doi:10.1016/S00221694(02)00036-7, 2002.

1191

Hubbard, B. and Nienow, P.: Alpine subglacial hydrology, Quat. Sci. Rev., 16(9), 939-955, doi:10.1016/S0277-3791(97)00031-0, 1997.

1193

1194

Hubbard, B., Heald, A., Reynolds, J. M., Quincey, D., Richardson, S. D., Luyo, M. Z., Portilla, N. S. and Hambrey, M. J.: Impact of a rock avalanche on a moraine-dammed proglacial lake: Laguna Safuna Alta, Cordillera Blanca, Peru, Earth Surf. Process. Landforms, 30(10), 1251-1264, doi:10.1002/esp.1198, 2005.

1196

1197

Hubbard, B., Milliken, R. E., Kargel, J. S., Limaye, A. and Souness, C.: Geomorphological characterisation and interpretation of a mid-latitude glacier-like form: Hellas Planitia, Mars, Icarus, 211(1), 330-346, doi:10.1016/j.icarus.2010.10.021, 2011.

Hubbard, B., Souness, C. and Brough, S.: Glacier-like forms on Mars, Cryosph., 8, 2047-2061, doi:10.5194/tc-8-2047-2014, 2014.

Huggel, C., Clague, J. J. and Korup, O.: Is climate change responsible for changing landslide activity in high mountains?, Earth Surf. Process. Landforms, 37(1), 77-91, doi:10.1002/esp.2223, 2012.

Huss, M.: Present and future contribution of glacier storage change to runoff from macroscale drainage basins in Europe, Water Resour. Res., 47(7), 1-14, doi:10.1029/2010WR010299, 2011. 
The Cryosphere Discuss., https://doi.org/10.5194/tc-2017-210

Manuscript under review for journal The Cryosphere

Discussion started: 2 November 2017

(c) Author(s) 2017. CC BY 4.0 License.

Immerzeel, W. W., van Beek, L. P. H. and Bierkens, M. F. P.: Climate change will affect the Asian water towers, Science (80-. )., 328, 1382-5, doi:10.1126/science.1183188, 2010.

Immerzeel, W. W., van Beek, L. P. H., Konz, M., Shrestha, A. B. and Bierkens, M. F. P.: Hydrological response to climate change in a glacierized catchment in the Himalayas, Clim. Change, 110(3-4), 721-736, doi:10.1007/s10584-011-0143-4, 2012.

Immerzeel, W. W., Kraaijenbrink, P. D. A., Shea, J. M., Shrestha, A. B., Pellicciotti, F., Bierkens, M. F. P. and De Jong, S. M.: High-resolution monitoring of Himalayan glacier dynamics using unmanned aerial vehicles, Remote Sens. Environ., 150, 93-103, doi:10.1016/j.rse.2014.04.025, 2014.

Inoue, J. and Yoshida, M.: Ablation and Heat Exchange over the Khumbu Glacier, J. Japanese Soc. Snow Ice, 41(Glaciological Expedition of Nepal, Contribution No. 65), 26-33, doi:10.5331/seppyo.41.Special_26, 1980.

Irvine-Fynn, T. D. L., Hodson, A. J., Moorman, B. J., Vatne, G. and Hubbard, A. L.: Polythermal Glacier Hydrology: A Review, Rev. Geophys., 49(2010), 1-37, doi:10.1029/2010RG000350.1.INTRODUCTION, 2011.

Iwata, S., Watanabe, O. and Fushimi, H.: Surface morphology in the ablation area of the Khumbu Glacier, J. Japanese Soc. Snow Ice, 41(Special), 9-17, 1980.

Iwata, S., Aoki, T., Kadota, T., Seko, K. and Yamaguchi, S.: Morphological evolution of the debris cover on Khumbu Glacier, Nepal, between 1978 and 1995, in Debris-Covered Glaciers, vol. 264, edited by M. Nakawo, C. F. Raymond, and A. Fountain, pp. 3-11, International Association of Hydrological Sciences, Oxford., 2000.

Jacobsen, D., Milner, A. M., Brown, L. E. and Dangles, O.: Biodiversity under threat in glacier-fed river systems, Nat. Clim. Chang., 2(5), 361-364, doi:10.1038/nclimate1435, 2012.

Janke, J. R., Bellisario, A. C. and Ferrando, F. A.: Classification of debris-covered glaciers and rock glaciers in the Andes of central Chile, Geomorphology, 241, 98-121, doi:10.1016/j.geomorph.2015.03.034, 2015.

Jansson, P., Naslund, J.-O., Pettersson, R., Richardson-Naslund, C. and Holmlund, P.: Debris entrainment and polythermal structure in the terminus of Storglaciaren, in Debris Covered Glaciers, edited by $M$. Nakawo, C. F. Raymond, and A. Fountain, pp. 143-151, International Association of Hydrological Sciences, Oxford. [online] Available from: http://books.google.com/books?hl=en\&lr=\&id=ghn8LV2CZ20C\&oi=fnd\&pg=PA143\&dq=Debris+entrain ment+and+polythermal+structure+in+the+terminus+of+Storglaciaren\&ots=RtmyzeOLF\&sig=wsOei42_Aiq1m9x99RLHGZYFH80, 2000.

Jansson, P., Hock, R. and Schneider, T.: The concept of glacier storage: a review, J. Hydrol., 282, 116-129, doi:10.1016/S0022-1694(03)00258-0, 2003.

Jarosch, A. H. and Gudmundsson, M. T.: A numerical model for meltwater channel evolution in glaciers, Cryosph., 6(2), 493-503, doi:10.5194/tc-6-493-2012, 2012.

Juen, M., Mayer, C., Lambrecht, A., Han, H. and Liu, S.: Impact of varying debris cover thickness on ablation: A case study for Koxkar Glacier in the Tien Shan, Cryosphere, 8(2), 377-386, doi:10.5194/tc-8-377-2014, 2014.

Kääb, A.: Combination of SRTM3 and repeat ASTER data for deriving alpine glacier flow velocities in the Bhutan Himalaya, Remote Sens. Environ., 94(4), 463-474, doi:10.1016/j.rse.2004.11.003, 2005.

Kääb, A., Berthier, E., Nuth, C., Gardelle, J. and Arnaud, Y.: Contrasting patterns of early twenty-first-century glacier mass change in the Himalayas, Nature, 488(7412), 495-498, doi:10.1038/nature11324, 2012.

Kamb, B.: Sliding motion of glaciers: Theory and observation, Rev. Geophys., 8(4), 673-728, 
The Cryosphere Discuss., https://doi.org/10.5194/tc-2017-210

Manuscript under review for journal The Cryosphere

Discussion started: 2 November 2017

(c) Author(s) 2017. CC BY 4.0 License.

doi:10.1029/RG008i004p00673, 1970.

1249

1250

1251

1252

1253

1254

1255

1256

1257

1258

1259

1260

1261

1262

1263

1264

1265

1266

1267

1268

1269

1270

1271

1272

1273

1274

1275

1276

1277

1278

1279

1280

1281

1282

1283

1284

1285

1286

1287

1288

1289
Karimi, N., Farokhnia, A., Karimi, L., Eftekhari, M. and Ghalkhani, H.: Combining optical and thermal remote sensing data for mapping debris-covered glaciers (Alamkouh Glaciers, Iran), Cold Reg. Sci. Technol., 71, 73-83, doi:10.1016/j.coldregions.2011.10.004, 2012.

Kattelmann, R.: Glacial lake outburst floods in the Nepal Himalaya: A manageable hazard?, Nat. Hazards, 28(1), 145-154, doi:10.1023/A:1021130101283, 2003.

Kayastha, R. B., Takeuchi, Y., Nakawo, M. and Ageta, Y.: Practical prediction of ice melting beneath various thickness of debris cover on Khumbu Glacier, Nepal, using a positive degree-day factor, in DebrisCovered Glaciers, edited by M. Nakawo, C. F. Raymond, and A. Fountain, pp. 71-81, International Association of Hydrological Sciences, Oxford., 2000.

Kehrwald, N. M., Thompson, L. G., Tandong, Y., Mosley-Thompson, E., Schotterer, U., Alfimov, V., Beer, J., Eikenberg, J. and Davis, M. E.: Mass loss on Himalayan glacier endangers water resources, Geophys. Res. Lett., 35(22), 2-7, doi:10.1029/2008GL035556, 2008.

Khan, A. A., Pant, N. C., Sarkar, A., Tandon, S. K., Thamban, M. and Mahalinganathan, K.: The Himalayan cryosphere: A critical assessment and evaluation of glacial melt fraction in the Bhagirathi basin, Geosci. Front., 8(1), 107-115, doi:10.1016/j.gsf.2015.12.009, 2017.

Kienholz, C., Herreid, S., Rich, J. L., Arendt, A. A., Hock, R. and Burgess, E. W.: Derivation and analysis of a complete modern-date glacier inventory for Alaska and northwest Canada, J. Glaciol., 61(227), 403-420, doi:10.3189/2015JoG14J230, 2015.

King, O., Quincey, D. J., Carrivick, J. L. and Rowan, A. V.: Spatial variability in mass loss of glaciers in the Everest region, central Himalaya, between 2000 and 2015, Cryosph., 11, 407-426, doi:10.5194/tc-201699, 2017.

Kirkbride, M.: Debris-Covered Glaciers, in Encyclopedia of Snow, Ice and Glaciers, edited by V. Singh, P. Singh, and U. Haritashya, pp. 180-182, Springer Netherlands., 2011.

Kirkbride, M. P.: The temporal significance of transitions from melting to calving termini in the glaciers of the central Southern Alps of New Zealand, The Holocene, 3(3), 232-240, 1993.

Kirkbride, M. P. and Deline, P.: The formation of supraglacial debris covers by primary dispersal from transverse englacial debris bands, Earth Surf. Process. Landforms, 38(15), 1779-1792, doi:10.1002/esp.3416, 2013.

Kirkbride, M. P. and Warren, C. R.: Calving processes at a grounded ice cliff, Ann. Glaciol., 24, 116-121, 1997.

Kirkbride, M. P. and Warren, C. R.: Tasman Glacier, New Zealand: 20th-century thinning and predicted calving retreat, Glob. Planet. Change, 22(1-4), 11-28, doi:10.1016/S0921-8181(99)00021-1, 1999.

Kodama, H. and Mae, S.: The Flow of Glaciers in the Khumbu Region, J. Japanese Soc. Snow Ice, 38(Glaciological Expedition to Nepal, Contribution), 31-36, 1976.

Komori, J.: Recent expansions of glacial lakes in the Bhutan Himalayas, Quat. Int., 184(1), 177-186, doi:10.1016/j.quaint.2007.09.012, 2008.

Kraaijenbrink, P., Shea, J., Pellicciotti, F., de Jong, S. and Immerzeel, W.: Object-based analysis of unmanned aerial vehicle imagery to map and characterise surface features on a debris-covered glacier, Remote Sens. Environ., 186, 581-595, doi:10.1016/j.rse.2016.09.013, 2016a.

Kraaijenbrink, P., Meijer, S. W., Shea, J. M., Pellicciotti, F., De Jong, S. M. and Immerzeel, W. W.: Seasonal surface velocities of a Himalayan glacier derived by automated correlation of unmanned aerial vehicle 
The Cryosphere Discuss., https://doi.org/10.5194/tc-2017-210

Manuscript under review for journal The Cryosphere

Discussion started: 2 November 2017

(c) Author(s) 2017. CC BY 4.0 License.

imagery, Ann. Glaciol., 57(71), 103-113, doi:10.3189/2016AoG71A072, 2016b.

1291

1292

1293

1294

1295

1296

1297

1298

1299

1300

1301

1302

1303

1304

1305

1306

1307

1308

1309

1310

1311

1312

1313

1314

1315

1316

1317

1318

1319

1320

1321

1322

1323

1324

1325

1326

1327

1328

1329

1330

1331
Kraaijenbrink, P. D. A., Bierkens, M. F. P., Lutz, A. F. and Immerzeel, W. W.: Impact of a global temperature rise of 1.5 degrees Celsius on Asia's glaciers, Nature, 549(7671), 257-260, doi:10.1038/nature23878, 2017.

Kumar, K., Miral, M. S., Joshi, S., Pant, N., Joshi, V. and Joshi, L. M.: Solute dynamics of meltwater of Gangotri glacier, Garhwal Himalaya, India, Environ. Geol., 58(6), 1151-1159, doi:10.1007/s00254-008-1592-6, 2009.

Kumar, S. and Dobhal, D. P.: Climatic effects and bedrock control on rapid fluctuations of Chhota Shigri glacier, northwest Himalaya, India, J. Glaciol., 43(145), 467-472, 1997.

Lambrecht, A., Mayer, C., Hagg, W., Popovnin, V., Rezepkin, A., Lomidze, N. and Svanadze, D.: A comparison of glacier melt on debris-covered glaciers in the northern and southern Caucasus, Cryosph., 5, 525-538, doi:10.5194/tc-5-525-2011, 2011.

Langston, G., Bentley, L. R., Hayashi, M., Mcclymont, A. and Pidlisecky, A.: Internal structure and hydrological functions of an alpine proglacial moraine, Hydrol. Process., 25(19), 2967-2982, doi:10.1002/hyp.8144, 2011.

Lejeune, Y., Bertrand, J., Wagnon, P. and Morin, S.: A physically based model of the year-round surface energy and mass balance of debris-covered glaciers, J. Glaciol., 59(214), 327-344, doi:10.3189/2013JoG12J149, 2013.

Levy, J. S., Marchant, D. R. and Head, J. W.: Distribution and origin of patterned ground on Mullins Valley debris-covered glacier, Antarctica: The roles of ice flow and sublimation, Antarct. Sci., 18(3), 385-397, doi:10.1002/dat.20032, 2006.

Liu, F., Williams, M. W. and Caine, N.: Source waters and flow paths in an alpine catchment, Colorado Front Range, United States, Water Resour. Res., 40(9), 1-16, doi:10.1029/2004WR003076, 2004.

Lowe, A. T. and Collins, D. N.: Modelling runoff from large glacierized basins in the Karakoram Himalaya using remote sensing of the transient snowline, Remote Sens. Hydrol., (267), 99-104, 2001.

Lukas, S., Nicholson, L., Ross, F. and Humlum, O.: Formation, Meltout Processes and Landscape Alteration of High-Arctic Ice-Cored Moraines - Examples from Nordenskiold Land, Central Spitsbergen, Polar Geogr., 29(3), 157-187, 2005.

Lutz, A. F., Immerzeel, W. W., Shrestha, A. B. and Bierkens, M. F. P.: Consistent increase in High Asia's runoff due to increasing glacier melt and precipitation, Nat. Clim. Chang., 4(7), 587-592, doi:10.1038/nclimate2237, 2014.

Mackay, S., Marchant, D., Lamp, J. and Head, J.: Cold-based debris-covered glaciers: Evaluating their potential as climate archives through studies of ground-penetrating radar and surface morphology, J. Geophys. Res. Earth Surf., 119, 2505-2540, doi:10.1002/2014JF003178.Received, 2014.

Mae, S.: Ice Temperature of Khumbu Glacier, J. Japanese Soc. Snow Ice, 38(Special), 37-38, 1976.

Mae, S., Wushiki, H., Ageta, Y. and Higuchi, K.: Thermal Drilling and Temperature Measurements in Khumbu Glacier, Nepal Measurements Himalayas, J. Japanese Soc. Snow Ice, 37(4), 161-169, 1975.

Mair, D., Nienow, P., Sharp, M., Wohlleben, T. and Willis, I.: Influence of subglacial drainage system evolution on glacier surface motion: Haut Glacier d'Arolla, Switzerland, J. Geophys. Res., 107(B8, 2175), 1-13, doi:10.1029/2001JB000514, 2002.

Marston, R.: Supraglacial Stream Dynamics on the Juneau Icefield, Ann. Assoc. Am. Geogr., 73(4), 597-608, 1983. 
The Cryosphere Discuss., https://doi.org/10.5194/tc-2017-210

Manuscript under review for journal The Cryosphere

Discussion started: 2 November 2017

(c) Author(s) 2017. CC BY 4.0 License.

Mattson, L. E.: The influence of a debris cover on the midsummer discharge of Dome Glacier, Canadian Rocky Mountains, in Debris-Covered Glaciers, edited by M. Nakawo, C. F. Raymond, and A. Fountain, pp. 25-33, International Association of Hydrological Sciences, Oxford. [online] Available from: http://books.google.co.uk/books?hl=en\&lr=\&id=ghn8LV2CZ20C\&oi=fnd\&pg=PA25\&dq=energy+excha nges+and+ablation+rates+on+the+debris+covered\&ots=RtmzubOMH6\&sig=riBkZ2YI9IMB5Ak5ceYpjyFhy8, 2000.

Mayer, C., Lambrecht, A., Belò, M., Smiraglia, C. and Diolaiuti, G.: Glaciological characteristics of the ablation zone of Baltoro glacier, Karakoram, Pakistan, Ann. Glaciol., 43, 123-131, doi:10.3189/172756406781812087, 2006.

McCarthy, M., Pritchard, H., Willis, I. A. N. and King, E.: Ground-penetrating radar measurements of debris thickness on Lirung Glacier, Nepal, J. Glaciol., 63(239), 543-555, doi:10.1017/jog.2017.18, 2017.

Mertes, J. R., Thompson, S. S., Booth, A. D., Gulley, J. D. and Benn, D. I.: A conceptual model of supraglacial lake formation on debris-covered glaciers based on GPR facies analysis., Earth Surf. Process. Landforms, doi:10.1002/esp.4068, 2016.

Mihalcea, C., Mayer, C., Diolaiuti, G., Lambrecht, A., Smiraglia, C. and Tartari, G.: Ice ablation and meteorological conditions on the debris-covered area of Baltoro glacier, Karakoram, Pakistan, Ann. Glaciol., 43(1894), 292-300, doi:10.3189/172756406781812104, 2006.

Mihalcea, C., Brock, B. W., Diolaiuti, G., D’Agata, C., Citterio, M., Kirkbride, M. P., Cutler, M. E. J. and Smiraglia, C.: Using ASTER satellite and ground-based surface temperature measurements to derive supraglacial debris cover and thickness patterns on Miage Glacier (Mont Blanc Massif, Italy), Cold Reg. Sci. Technol., 52(3), 341-354, doi:10.1016/j.coldregions.2007.03.004, 2008.

Miles, E. S., Pellicciotti, F., Willis, I. C., Steiner, J. F., Buri, P. and Arnold, N. S.: Refined energy-balance modelling of a supraglacial pond, Langtang Khola, Nepal, Ann. Glaciol., 57(71), 29-40, doi:10.3189/2016AoG71A421, 2016a.

Miles, E. S., Willis, I. C., Arnold, N. S., Steiner, J. F. and Pellicciotti, F.: Spatial, seasonal, and interannual variability of supraglacial ponds in the Langtang Valley of Nepal, 1999 to 2013, J. Glaciol., 1-18, doi:10.1017/jog.2016.120, 2016b.

Miles, E. S., Steiner, J., Willis, I. C., Buri, P., Immerzeel, W. W., Chesnokova, A. and Pellicciotti, F.: Pond dynamics and supraglacial-englacial connectivity on debris-covered Lirung Glacier, Front. Earth Sci., doi:10.3389/feart.2017.00069, 2017.

Milner, A., Brown, L. and Hannah, D.: Hydroecological response of river systems to shrinking glaciers, Hydrol. Process., 23, 62-77, doi:10.1002/hyp, 2009.

Nagai, H., Fujita, K., Nuimura, T. and Sakai, A.: Southwest-facing slopes control the formation of debriscovered glaciers in the Bhutan Himalaya, Cryosph., 7(4), 1303-1314, doi:10.5194/tc-7-1303-2013, 2013.

Narama, C., Daiyrov, M., Tadono, T., Yamamoto, M., Kääb, A., Morita, R. and Jinro, U.: Seasonal drainage of supraglacial lakes on debris-covered glaciers in the Tien Shan Mountains, Central Asia, Geomorphology, doi:10.1016/j.geomorph.2017.03.002, 2017.

Nicholson, L. and Benn, D. I.: Calculating ice melt beneath a debris layer using meteorological data, J. Glaciol., 52(178), 463-470, doi:10.3189/172756506781828584, 2006.

Nicholson, L. and Benn, D. I.: Properties of natural supraglacial debris in relation to modelling sub-debris ice ablation, Earth Surf. Process. Landforms, 38(5), 490-501, doi:10.1002/esp.3299, 2013.

Nie, Y., Liu, Q. and Liu, S.: Glacial lake expansion in the Central Himalayas by landsat images, 1990-2010, PLoS One, 8(12), 1-8, doi:10.1371/journal.pone.0083973, 2013. 
The Cryosphere Discuss., https://doi.org/10.5194/tc-2017-210

Manuscript under review for journal The Cryosphere

Discussion started: 2 November 2017

(c) Author(s) 2017. CC BY 4.0 License.

Nienow, P., Sharp, M. and Willis, I.: Seasonal changes in the morphology of the subglacial drainage system, Haut Glacier d'Arolla, Switzerland, Earth Surf. Process. Landforms, 23(9), 825-843, doi:10.1002/(SICI)1096-9837(199809)23:9<825::AID-ESP893>3.0.CO;2-2, 1998.

Nuimura, T., Fujita, K., Yamaguchi, S. and Sharma, R. R.: Elevation changes of glaciers revealed by multitemporal digital elevation models calibrated by GPS survey in the Khumbu region, Nepal Himalaya, 1992-2008, J. Glaciol., 58(210), 648-656, doi:10.3189/2012JoG11J061, 2012.

Nye, J.: The Distribution of Stress and Velocity in Glaciers and Ice-Sheets, Proc. R. Soc. A Math. Phys. Eng. Sci., 239(1216), 113-133, 1957.

Nye, J. F.: A Calculation on the Sliding of Ice Over a Wavy Surface Using a Newtonian Viscous Approximation, Proc. R. Soc. A Math. Phys. Eng. Sci., 311(1506), 445-467, doi:10.1098/rspa.1969.0127, 1969.

Osti, R., Bhattarai, T. N. and Miyake, K.: Causes of catastrophic failure of Tam Pokhari moraine dam in the Mt. Everest region, Nat. Hazards, 58(3), 1209-1223, doi:10.1007/s11069-011-9723-x, 2011.

$\varnothing$ strem, G.: Ice Melting under a Thin Layer of Moraine, and the Existence of Ice Cores in Moraine Ridges, Geogr. Ann., 41(4), 228-230, 1959.

Paul, F., Huggel, C. and Kääb, A.: Combining satellite multispectral image data and a digital elevation model for mapping debris-covered glaciers, Remote Sens. Environ., 89(4), 510-518, doi:10.1016/j.rse.2003.11.007, 2004.

Pellicciotti, F., Stephan, C., Miles, E., Herreid, S., Immerzeel, W. W. and Bolch, T.: Mass-balance changes of the debris-covered glaciers in the Langtang Himal, Nepal, from 1974 to 1999, J. Glaciol., 61(226), 373386, doi:10.3189/2015JoG13J237, 2015.

Pelto, M. S.: Mass balance of adjacent debris-covered and clean glacier ice in the North Cascades, Washington, in Debris-Covered Glaciers, edited by M. Nakawo, C. F. Raymond, and A. Fountain, pp. 3542, International Association of Hydrological Sciences, Oxford., 2000.

Pieczonka, T., Bolch, T., Junfeng, W. and Shiyin, L.: Heterogeneous mass loss of glaciers in the Aksu-Tarim Catchment (Central Tien Shan) revealed by 1976 KH-9 Hexagon and 2009 SPOT-5 stereo imagery, Remote Sens. Environ., 130, 233-244, doi:10.1016/j.rse.2012.11.020, 2013.

Planet Team: Planet Application Program Interface: In Space for Life on Earth, [online] Available from: https://api.planet.com, 2017.

Pottakkal, J. G., Ramanathan, A., Singh, V. B., Sharma, P., Azam, M. F. and Linda, A.: Characterization of subglacial pathways draining two tributary meltwater streams through the lower ablation zone of Gangotri glacier system, Garhwal Himalaya, India, Curr. Sci., 107(4), 613-621, 2014.

Pritchard, H. D.: Asia's glaciers are a regionally important buffer against drought, Nature, 545(7653), 169174, doi:10.1038/nature22062, 2017.

Qiao, L., Mayer, C. and Liu, S.: Distribution and interannual variability of supraglacial lakes on debris-covered glaciers in the Khan Tengri-Tumor Mountains, Central Asia, Environ. Res. Lett., 10(1), 1-10, doi:10.1088/1748-9326/10/1/014014, 2015.

Quincey, D. J., Richardson, S. D., Luckman, A., Lucas, R. M., Reynolds, J. M., Hambrey, M. J. and Glasser, N. F.: Early recognition of glacial lake hazards in the Himalaya using remote sensing datasets, Glob. Planet. Change, 56(1-2), 137-152, doi:10.1016/j.gloplacha.2006.07.013, 2007.

Quincey, D. J., Copland, L., Mayer, C., Bishop, M., Luckman, A. and Belò, M.: Ice velocity and climate variations for Baltoro Glacier, Pakistan, J. Glaciol., 55(194), 1061-1071, doi:10.3189/002214309790794913, 2009. 
The Cryosphere Discuss., https://doi.org/10.5194/tc-2017-210

Manuscript under review for journal The Cryosphere

Discussion started: 2 November 2017

(c) Author(s) 2017. CC BY 4.0 License.

Racoviteanu, A. E., Arnaud, Y., Williams, M. W. and Ordoñez, J.: Decadal changes in glacier parameters in the Cordillera Blanca, Peru, derived from remote sensing, J. Glaciol., 54(186), 499-510, 2008.

Radić, V., Bliss, A., Beedlow, A. C., Hock, R., Miles, E. and Cogley, J. G.: Regional and global projections of twenty-first century glacier mass changes in response to climate scenarios from global climate models, Clim. Dyn., 42(1-2), 37-58, doi:10.1007/s00382-013-1719-7, 2014.

Ragettli, S., Pellicciotti, F., Immerzeel, W. W., Miles, E. S., Petersen, L., Heynen, M., Shea, J. M., Stumm, D., Joshi, S. and Shrestha, A.: Unraveling the hydrology of a Himalayan catchment through integration of high resolution in situ data and remote sensing with an advanced simulation model, Adv. Water Resour., 78, 94-111, doi:10.1016/j.advwatres.2015.01.013, 2015.

Ragettli, S., Immerzeel, W. W. and Pellicciotti, F.: Contrasting climate change impact on river flows from high-altitude catchments in the Himalayan and Andes Mountains, Proc. Natl. Acad. Sci. U. S. A., 113(33), 9222-9227, doi:10.1073/pnas.1606526113, 2016a.

Ragettli, S., Bolch, T. and Pellicciotti, F.: Heterogeneous glacier thinning patterns over the last 40 years in Langtang Himal, Nepal, Cryosph., 10(5), 2075-2097, doi:10.5194/tc-10-2075-2016, 2016b.

Rana, B., Nakawo, M., Fukushima, Y. and Ageta, Y.: Application of a conceptual precipitation-runoff model (HYCYMODEL) in a debris-covered glacierized basin in the Langtang Valley, Nepal Himalaya, Ann. Glaciol., 25(199 0), 226-231, 1997.

Rana, B., Shrestha, A. B., Reynolds, J. M., Aryal, R., Pokhrel, A. P. and Budhathoki, K. P.: Hazard assessment of the Tsho Rolpa Glacier Lake and ongoing, J. Nepal Geol. Soc., 22, 563-570, 2000.

Raymond, C. F. C. and Nolan, M.: Drainage of a glacial lake through an ice spillway, in Symposium: DebrisCovered Glaciers, edited by M. Nakawo, C. F. Raymond, and A. Fountain, pp. 199-210, International Association of Hydrological Sciences, Oxford. [online] Available from: http://books.google.com/books?hl=en\&lr=\&id=ghn8LV2CZ20C\&oi=fnd\&pg=PA199\&dq=Drainage+of+a +glacial+lake+through+an+ice+spillway\&ots=RsuGBdMSH6\&sig=UxOhTWO5tWIE4-kW4eg3PjGNxsg, 2000.

Rees, G. and Collins, D.: Regional differences in response of flow in glacier-fed Himalayan rivers to climatic warming, Hydrol. Process., 20, 2157-2169, doi:10.1002/hyp, 2006.

Reid, T. D. and Brock, B. W.: An energy-balance model for debris-covered glaciers including heat conduction through the debris layer, J. Glaciol., 56(199), 903-916, 2010.

Reid, T. D. and Brock, B. W.: Assessing ice-cliff backwasting and its contribution to total ablation of debriscovered Miage glacier, Mont Blanc massif, Italy, J. Glaciol., 60(219), 3-13, doi:10.3189/2014JoG13J045, 2014.

Reynolds, J. M.: On the formation of supraglacial lakes on debris-covered glaciers, Debris-covered glaciers, 264(264), 153-161, 2000.

Richardson, S. D. and Reynolds, J. M.: Degradation of ice-cored moraine dams: implications for hazard development, Debris-covered glaciers Proc. an Int. Work. held Univ. Washingt. Seattle, Washington, USA, (264), 187-197, 2000.

Rist, A. and Phillips, M.: First results of investigations on hydrothermal processes within the active layer above alpine permafrost in steep terrain, Nor. Geogr. Tidsskr. - Nor. J. Geogr., 59(2), 177-183, doi:10.1080/00291950510020574, 2005.

Rivera, A., Benham, T., Casassa, G., Bamber, J. and Dowdeswell, J. A.: Ice elevation and areal changes of glaciers from the Northern Patagonia Icefield, Chile, Glob. Planet. Change, 59(1-4), 126-137, doi:10.1016/j.gloplacha.2006.11.037, 2007. 
The Cryosphere Discuss., https://doi.org/10.5194/tc-2017-210

Manuscript under review for journal The Cryosphere

Discussion started: 2 November 2017

(c) Author(s) 2017. CC BY 4.0 License.

1460

1461

1462

1463

1464

1465

1466

1467

1468

1469

1470

1471

1472

1473

1474

1475

1476

1477

1478

1479

1480

1481

1482

1483

1484

1485

1486

1487

1488

1489

1490

1491

1492

1493

1494

1495

1496

1497

1498

1499

1500

1501

Robertson, C. M., Benn, D. I., Brook, M. S., Fuller, I. C. and Holt, K. A.: Subaqueous calving margin morphology at Mueller, Hooker and Tasman glaciers in Aoraki/Mount Cook National Park, New Zealand, J. Glaciol., 58(212), 1037-1046, doi:10.3189/2012JoG12J048, 2012.

Röhl, K.: Thermo-erosional notch development at fresh-water-calving Tasman Glacier, New Zealand, J. Glaciol., 52(177), 203-213, doi:10.3189/172756506781828773, 2006.

Röhl, K.: Characteristics and evolution of supraglacial ponds on debris-covered Tasman Glacier, New Zealand, J. Glaciol., 54(188), 867-880, doi:10.3189/002214308787779861, 2008.

Rounce, D., Byers, A. C., Byers, E. A. and McKinney, D. C.: Brief Communications: Observations of a glacier outburst flood from Lhotse Glacier, Everest area, Nepal, Cryosph., 11, 443-449, doi:10.5194/tc-2016239, 2017.

Rounce, D. R., Quincey, D. J. and McKinney, D. C.: Debris-covered glacier energy balance model for ImjaLhotse Shar Glacier in the Everest region of Nepal, Cryosph., 9(6), 2295-2310, doi:10.5194/tc-9-22952015, 2015.

Rounce, D. R., McKinney, D. C., Lala, J. M., Byers, A. C. and Watson, C. S.: A New Remote Hazard and Risk Assessment Framework for Glacial Lakes in the Nepal Himalaya, Hydrol. Earth Syst. Sci., (20), 3455-3475, doi:10.5194/hess-2016-161, 2016.

Rowan, A. V., Egholm, D. L., Quincey, D. J. and Glasser, N. F.: Modelling the feedbacks between mass balance, ice flow and debris transport to predict the response to climate change of debris-covered glaciers in the Himalaya, Earth Planet. Sci. Lett., 430, 427-438, doi:10.1016/j.epsl.2015.09.004, 2015.

Roy, J. W. and Hayashi, M.: Multiple, distinct groundwater flow systems of a single moraine-talus feature in an alpine watershed, J. Hydrol., 373(1-2), 139-150, doi:10.1016/j.jhydrol.2009.04.018, 2009.

Sakai, A.: Glacial Lakes in the Himalayas : A Review on Formation and Expansion Processes, Glob. Environ. Res., 16(2011), 23-30, 2012.

Sakai, A. and Fujita, K.: Formation conditions of supraglacial lakes on debris-covered glaciers in the Himalaya, J. Glaciol., 56(195), 9249-9251, 2010.

Sakai, A., Nakawo, M. and Fujita, K.: Melt rate of ice cliffs on the Lirung Glacier, Nepal Himalayas, 1996, Bull. Glacier Res., 16(October), 57-66, 1998.

Sakai, A., Takeuchi, N., Fujita, K. and Nakawo, M.: Role of supraglacial ponds in the ablation process of a debris-covered glacier in the Nepal Himalayas, in Debris-Covered Glaciers, edited by M. Nakawo, C. F. Raymond, and A. Fountain, pp. 119-130, International Association of Hydrological Sciences, Oxford., 2000.

Sakai, A., Nakawo, M. and Fujita, K.: Distribution Characteristics and Energy Balance of Ice Cliffs on DebrisCovered Glaciers, Nepal Himalaya, Arctic, Antarct. Alp. Res., 34(1), 12-19, 2002.

Sakai, A., Nishimura, K., Kadota, T. and Takeuchi, N.: Onset of calving at supraglacial lakes on debris-covered glaciers of the Nepal Himalaya, J. Glaciol., 55(193), 909-917, doi:10.3189/002214309790152555, 2009.

Salerno, F., Thakuri, S., D’Agata, C., Smiraglia, C., Manfredi, E. C., Viviano, G. and Tartari, G.: Glacial lake distribution in the Mount Everest region: Uncertainty of measurement and conditions of formation, Glob. Planet. Change, 92-93, 30-39, doi:10.1016/j.gloplacha.2012.04.001, 2012.

Salerno, F., Guyennon, N., Thakuri, S., Viviano, G., Romano, E., Vuillermoz, E., Cristofanelli, P., Stocchi, P., Agrillo, G., Ma, Y. and Tartari, G.: Weak precipitation, warm winters and springs impact glaciers of south slopes of Mt. Everest (central Himalaya) in the last 2 decades (1994-2013), Cryosph., 9(3), 1229-1247, doi:10.5194/tc-9-1229-2015, 2015. 
The Cryosphere Discuss., https://doi.org/10.5194/tc-2017-210

Manuscript under review for journal The Cryosphere

Discussion started: 2 November 2017

(c) Author(s) 2017. CC BY 4.0 License.

Sasaki, O., Noguchi, O., Zhang, Y., Hirabayashi, Y. and Kanae, S.: A global high-resolution map of debris on glaciers derived from multi-temporal ASTER images, Cryosph. Discuss., (November), 1-24, doi:10.5194/tc-2016-222, 2016.

Savéan, M., Delclaux, F., Chevallier, P., Wagnon, P., Gonga-Saholiariliva, N., Sharma, R., Neppel, L. and Arnaud, Y.: Water budget on the Dudh Koshi River (Nepal): Uncertainties on precipitation, J. Hydrol., 531, 850-862, doi:10.1016/j.jhydrol.2015.10.040, 2015.

Scherler, D., Bookhagen, B. and Strecker, M. R.: Spatially variable response of Himalayan glaciers to climate change affected by debris cover, Nat. Geosci., 4(3), 156-159, doi:10.1038/ngeo1068, 2011.

Schmid, M. O., Baral, P., Gruber, S., Shahi, S., Shrestha, T., Stumm, D. and Wester, P.: Assessment of permafrost distribution maps in the Hindu Kush Himalayan region using rock glaciers mapped in Google Earth, Cryosph., 9(6), 2089-2099, doi:10.5194/tc-9-2089-2015, 2015.

Sharp, M., Brown, G. H., Tranter, M., Willis, I. C. and Hubbard, B.: Comments on the use of chemically based mixing models in glacier hydrology, J. Glaciol., 41(138), 241-246, doi:10.1207/s15327752jpa8502, 1995.

Shea, J. M. and Immerzeel, W. W.: An assessment of basin-scale glaciological and hydrological sensitivities in the Hindu Kush-Himalaya, Ann. Glaciol., 57(71), 308-318, doi:10.3189/2016AoG71A073, 2016.

Shea, J. M., Immerzeel, W. W., Wagnon, P., Vincent, C. and Bajracharya, S.: Modelling glacier change in the Everest region, Nepal Himalaya, Cryosph., 9(3), 1105-1128, doi:10.5194/tc-9-1105-2015, 2015.

Shreve, R. L.: Movement of water in glaciers, J. Glaciol., 11, 205-214, doi: 10.3189/S002214300002219X, 1972.

Singh, P. and Bengtsson, L.: Hydrological sensitivity of a large Himalayan basin to climate change, Hydrol. Process., 18(13), 2363-2385, doi:10.1002/hyp.1468, 2004.

Singh, P., Ramasastri, K. S., Singh, U. K., Gergan, J. T. and Dobhal, D. P.: Hydrological characteristics of the Dokriani Glacier in the Garhwal Himalayas, Hydrol. Sci. J., 40(2), 243-257, doi:10.1080/02626669509491407, 1995.

Singh, P., Kumar, N., Ramasastri, K. S. and Singh, Y.: Influence of a fine debris layer on the melting of snow and ice on a Himalayan glacier, in Debris-Covered Glaciers, edited by M. Nakawo, C. F. Raymond, and A. Fountain, pp. 63-69, International Association of Hydrological Sciences, Oxford., 2000.

Singh, P., Haritashya, U. K., Ramasastri, K. S. and Kumar, N.: Diurnal variations in discharge and suspended sediment concentration, including runoff-delaying characteristics, of the Gangotri Glacier in the Garhwal Himalayas, Hydrol. Process., 19(7), 1445-1457, doi:10.1002/hyp.5583, 2005.

Singh, P., Arora, M. and Goel, N. K.: Effect of climate change on runoff of a glacierized Himalayan basin, Hydrol. Process., 20(9), 1979-1992, doi:10.1002/hyp.5991, 2006a.

Singh, P., Haritashya, U. K., Kumar, N. and Singh, Y.: Hydrological characteristics of the Gangotri Glacier, central Himalayas, India, J. Hydrol., 327(1-2), 55-67, doi:10.1016/j.jhydrol.2005.11.060, 2006b.

Singh, P., Haritashya, U. and Kumar, N.: Modelling and estimation of different components of streamflow for Gangotri Glacier basin, Himalayas, Hydrol. Sci. J., 53(2), 309-322, doi:10.1623/hysj.53.2.309, 2008.

Smart, C. C.: Artificial Tracer Techniques for the Determination of the Structure of Conduit Aquifers, Groundwater, 26(4), 445-453, doi:10.1111/j.1745-6584.1988.tb00411.x, 1988.

Smart, C. C.: Statistical evaluation of glacier boreholes as indicators of basal drainage systems, Hydrol. Process., 10(4), 599-613, doi:10.1002/(sici)1099-1085(199604)10:4<599::aid-hyp394>3.0.co;2-8, 1996.

Soncini, A., Bocchiola, D., Confortola, G., Minora, U., Vuillermoz, E., Salerno, F., Viviano, G., Shrestha, D., 
The Cryosphere Discuss., https://doi.org/10.5194/tc-2017-210

Manuscript under review for journal The Cryosphere

Discussion started: 2 November 2017

(c) Author(s) 2017. CC BY 4.0 License.

Senese, A., Smiraglia, C. and Diolaiuti, G.: Future hydrological regimes and glacier cover in the Everest region: The case study of the upper Dudh Koshi basin, Sci. Total Environ., 1084-1101, doi:10.1016/j.scitotenv.2016.05.138, 2016.

Sorg, A., Bolch, T., Stoffel, M., Solomina, O. and Beniston, M.: Climate change impacts on glaciers and runoff in Tien Shan (Central Asia), Nat. Clim. Chang., 2(10), 725-731, doi:10.1038/nclimate1592, 2012.

Souness, C., Hubbard, B., Milliken, R. E. and Quincey, D.: An inventory and population-scale analysis of martian glacier-like forms, Icarus, 217(1), 243-255, doi:10.1016/j.icarus.2011.10.020, 2012.

Spedding, N.: Hydrological controls on sediment transport pathways: implications for debris-covered glaciers, in Debris-covered Glaciers, edited by M. Nakawo, C. F. Raymond, and A. Fountain, pp. 133-142, International Association of Hydrological Sciences, Oxford. [online] Available from: https://books.google.co.uk/books?hl=en\&lr=\&id=ghn8LV2CZ20C\&oi=fnd\&pg=PA133\&dq=hydrological +controls+spedding+sediment+transport\&ots=RtpBt5MQK1\&sig=i0g_gHXs7o-_ZDS3qPvTRzjzk5g, 2000.

Stokes, C. R., Popovnin, V., Aleynikov, A., Gurney, S. D. and Shahgedanova, M.: Recent glacier retreat in the Caucasus Mountains, Russia, and associated increase in supraglacial debris cover and supra-/proglacial lake development, Ann. Glaciol., 46(5642 m), 195-203, doi:10.3189/172756407782871468, 2007.

Sundal, A. V., Shepherd, A., Nienow, P., Hanna, E., Palmer, S. and Huybrechts, P.: Evolution of supra-glacial lakes across the Greenland Ice Sheet, Remote Sens. Environ., 113(10), 2164-2171, doi:10.1016/j.rse.2009.05.018, 2009.

Takeuchi, N., Sakai, A., Kohshima, S., Fujita, K., Nakawo, M., Shiro, K., Fujita, K. and Masayoshi, N.: Variation in Suspended Sediment Concentration of Supraglacial Lakes on Debris-covered Area of the Lirung Glacier in the Nepal Himalayas, Glob. Environ. Res., 16(July), 95-104 [online] Available from: http://wwwes.s.chiba-u.ac.jp/\%7B \%7Dtakeuchi/pdf/12ger\%7B_\%7DLirung\%7B_\%7Dlake.pdf, 2012.

Takeuchi, Y., Kayastha, R. B. and Nakawo, M.: Characteristics of ablation and heat balance in debris-free and debris-covered areas on Khumbu Glacier, Nepal Himalayas, in the pre-monsoon season, in DebrisCovered Glaciers, vol. 264, edited by M. Nakawo, C. F. Raymond, and A. Fountain, pp. 53-61, International Association of Hydrological Sciences, Oxford., 2000.

Tangborn, W. and Rana, B.: Mass balance and runoff of the partially debris- covered Langtang Glacier, Nepal, in Debris-Covered Glaciers, edited by M. Nakawo, C. F. Raymond, and A. Fountain, pp. 99-108, International Association of Hydrological Sciences, Oxford., 2000.

Thakuri, S., Salerno, F., Smiraglia, C., Bolch, T., D’Agata, C., Viviano, G. and Tartari, G.: Tracing glacier changes since the 1960s on the south slope of Mt. Everest (central Southern Himalaya) using optical satellite imagery, Cryosph., 8(4), 1297-1315, doi:10.5194/tc-8-1297-2014, 2014.

Thakuri, S., Salerno, F., Bolch, T., Guyennon, N. and Tartari, G.: Factors controlling the accelerated expansion of Imja Lake, Mount Everest region, Nepal, Ann. Glaciol., 57(71), 245-257, doi:10.3189/2016AoG71A063, 2016.

Thayyen, R. J. and Gergan, J. T.: Role of glaciers in watershed hydrology : a preliminary study of a "Himalayan catchment," Cryosph., 4, 115-128, doi:10.5194/tcd-3-443-2009, 2010.

Thayyen, R. J., Gergan, J. T. and Dobhal, D. P.: Monsoonal control on glacier discharge and hydrograph characteristics, a case study of Dokriani Glacier, Garhwal Himalaya, India, J. Hydrol., 306(1-4), 37-49, doi:10.1016/j.jhydrol.2004.08.034, 2005.

Thompson, S., Benn, D. I., Mertes, J. and Luckman, A.: Stagnation and mass loss on a Himalayan debriscovered glacier: Processes, patterns and rates, J. Glaciol., 62(233), 467-485, doi:10.1017/jog.2016.37, 2016. 
The Cryosphere Discuss., https://doi.org/10.5194/tc-2017-210

Manuscript under review for journal The Cryosphere

Discussion started: 2 November 2017

(c) Author(s) 2017. CC BY 4.0 License.

Thompson, S. S., Benn, D. I., Dennis, K. and Luckman, A.: A rapidly growing moraine-dammed glacial lake on Ngozumpa Glacier, Nepal, Geomorphology, 145-146, 1-11, doi:10.1016/j.geomorph.2011.08.015, 2012.

Tranter, M., Brown, G., Raiswell, R., Sharp, M. and Gurnell, A.: A conceptual model of solute acquisition by Alpine glacial meltwaters, J. Glaciol., 39(133), 573-581, doi:10.3198/1993JoG39-133-573-581, 1993.

Tranter, M., Sharp, M. J., Lamb, H. R., Brown, G. H., Hubbard, B. P. and Willis, I. C.: Geochemical weathering at the bed of Haut glacier d'Arolla, Switzerland - a new model, Hydrol. Process., 16(5), 959-993, doi:10.1002/hyp.309, 2002.

Vaughan, D. G., Comiso, J. C., Allison, I., Carrasco, J., Kaser, G., Kwok, R., Mote, P., Murray, T., Paul, F., Ren, J., Rignot, E., Solomina, O., Steffen, K. and Zhang, T.: Observations: Cryosphere, in Climate Change 2013: The Physical Science Basis. Contribution of Working Group I to the Fifth Assessment Report of the Intergovernmental Panel on Climate Change, edited by T. F. Stocker, G.-K. D. Qin, M. Plattner, S. Tignor, K. Allen, J. Boschung, A.Nauels, Y. Xia, V. Bex, and P. M. Midgley, pp. 317-382, Cambridge University Press, Cambridge, United Kingdom and New York, NY, USA., 2013.

Viste, E. and Sorteberg, A.: Snowfall in the Himalayas: an uncertain future from a little-known past, Cryosph., 9(3), 1147-1167, doi:10.5194/tc-9-1147-2015, 2015.

Vuichard, D. and Zimmermann, M.: The 1985 Catastrophic Drainage of a Moraine-Dammed Lake, Khumbu Himal, Nepal : Cause and Consequences, Mt. Res. Dev., 7(2), 91-110, 1987.

Walder, J. and Fowler, A.: Channelized subglacial drainage over a deformable bed, J. Glaciol., 40(134), 315, 1994.

Wang, X., Ding, Y., Liu, S., Jiang, L., Wu, K., Jiang, Z. and Guo, W.: Changes of glacial lakes and implications in Tian Shan, central Asia, based on remote sensing data from 1990 to 2010, Environ. Res. Lett., 8(4), 44052, doi:10.1088/1748-9326/8/4/044052, 2013.

Watanabe, T., Lamsal, D. and Ives, J. D.: Evaluating the growth characteristics of a glacial lake and its degree of danger of outburst flooding: Imja Glacier, Khumbu Himal, Nepal, Nor. Geogr. Tidsskr. - Nor. J. Geogr., 63(4), 255-267, doi:10.1080/00291950903368367, 2009.

Watson, C. S., Carrivick, J. and Quincey, D.: An improved method to represent DEM uncertainty in glacial lake outburst flood propagation using stochastic simulations, J. Hydrol., 529, 1373-1389, doi:10.1016/j.jhydrol.2015.08.046, 2015.

Watson, C. S., Quincey, D. J., Carrivick, J. L. and Smith, M. W.: The dynamics of supraglacial ponds in the Everest region, central Himalaya, Glob. Planet. Change, 142, 14-27, doi:10.1016/j.gloplacha.2016.04.008, 2016.

Watson, C. S., Quincey, D. J., Carrivick, J. L. and Smith, M. W.: Ice cliff dynamics in the Everest region of the Central Himalaya, Geomorphology, 278, 238-251, doi:10.1016/j.gloplacha.2016.04.008, 2017.

Weertman, J.: On the sliding of glaciers, J. Glaciol., 3, 33-38, doi:10.1007/978-94-015-8705-1_19, 1957.

Weertman, J.: Creep Deformation of Ice, Annu. Rev. Earth Planet. Sci., 11, 215-240, 1983.

Wessels, R. L., Kargel, J. S. and Kieffer, H. H.: ASTER measurement of supraglacial lakes in the Mount Everest region of the Himalaya, Ann. Glaciol., 34, 399-408, doi:10.3189/172756402781817545, 2002.

Wilhelm, L., Singer, G. A., Fasching, C., Battin, T. J. and Besemer, K.: Microbial biodiversity in glacier-fed streams, ISME J., 7(8), 1651-1660, doi:10.1038/ismej.2013.44, 2013.

Wilson, A. M., Williams, M. W., Kayastha, R. B. and Racoviteanu, A.: Use of a hydrologic mixing model to examine the roles of meltwater, precipitation and groundwater in the Langtang River basin, Nepal, Ann. 
The Cryosphere Discuss., https://doi.org/10.5194/tc-2017-210

Manuscript under review for journal The Cryosphere

Discussion started: 2 November 2017

(c) Author(s) 2017. CC BY 4.0 License.

Winiger, M., Gumpert, M. and Yamout, H.: Karakorum-Hindukush-western Himalaya: Assessing highaltitude water resources, Hydrol. Process., 19(12), 2329-2338, doi:10.1002/hyp.5887, 2005.

Winter, T. C.: The concept of hydrologic landscapes, J. Am. Water Resour. Assoc., 37(2), 335-349, doi:10.1111/j.1752-1688.2001.tb00973.x, 2001.

1634 Woo, M.: Permafrost Hydrology, Springer, Berlin., 2012.

1635

Woo, M. -K and Xia, Z.: Suprapermafrost groundwater seepage in gravelly terrain, Resolute, NWT, Canada,

1636 Permafr. Periglac. Process., 6(1), 57-72, doi:10.1002/ppp.3430060107, 1995.

1637

1638

Xin, W., Shiyin, L., Haidong, H., Jian, W. and Qiao, L.: Thermal regime of a supraglacial lake on the debriscovered Koxkar Glacier, southwest Tianshan, China, Environ. Earth Sci., 67(1), 175-183, doi:10.1007/s12665-011-1490-1, 2012.

1640

1641

1642

Zeng, C., Liu, Z., Yang, J. and Yang, R.: A groundwater conceptual model and karst-related carbon sink for a glacierized alpine karst aquifer, Southwestern China, J. Hydrol., 529(P1), 120-133, doi:10.1016/j.jhydrol.2015.07.027, 2015.

1643

1644

Zhang, Y., Liu, S. and Ding, Y.: Glacier meltwater and runoff modelling, Keqicar Baqi glacier, southwestern Tien Shan, China, J. Glaciol., 53(180), 91-98, doi:10.3189/172756507781833956, 2007.

1645

Zhao, L., Ding, R. and Moore, J. C.: Glacier volume and area change by 2050 in high mountain Asia, Glob. Planet. Change, 122, 197-207, doi:10.1016/j.gloplacha.2014.08.006, 2014.

1647 
The Cryosphere Discuss., https://doi.org/10.5194/tc-2017-210

Manuscript under review for journal The Cryosphere

Discussion started: 2 November 2017

(c) Author(s) 2017. CC BY 4.0 License.

\section{Figures}
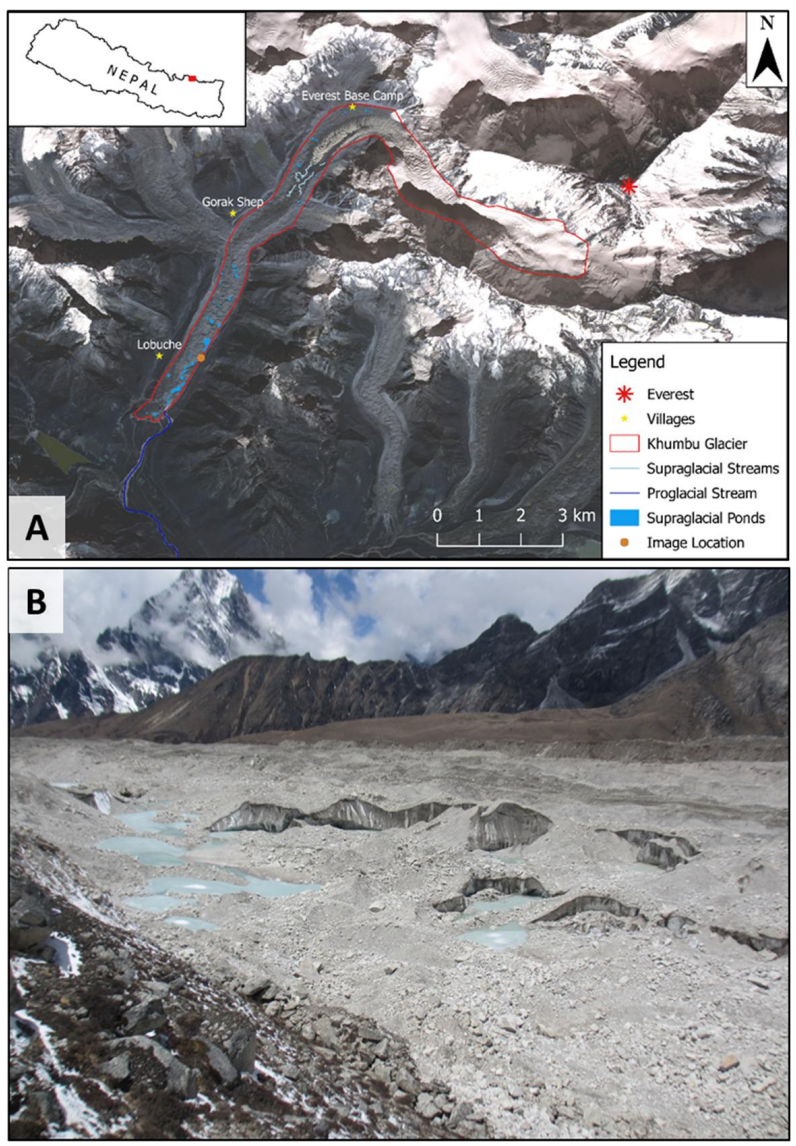

Figure 1 - An example of a typical and particularly well-studied DCG, Khumbu Glacier, Nepal Himalaya. (A) shows a RapidEye image of the glacier acquired on 17.11.2016 (Planet Team, 2017). The major supraglacial hydrological features (larger supraglacial ponds, supraglacial lakes and any supraglacial streams), the proglacial stream and the location from which the image in (B) was acquired are labelled. (B) shows an oblique photograph looking across the glacier surface (image acquisition location shown in (A), taken in the direction of the glacier terminus), also showing some of the supraglacial ponds as well as ice cliffs and variable surface topography. Image credit: KM 
The Cryosphere Discuss., https://doi.org/10.5194/tc-2017-210

Manuscript under review for journal The Cryosphere

Discussion started: 2 November 2017

(c) Author(s) 2017. CC BY 4.0 License.
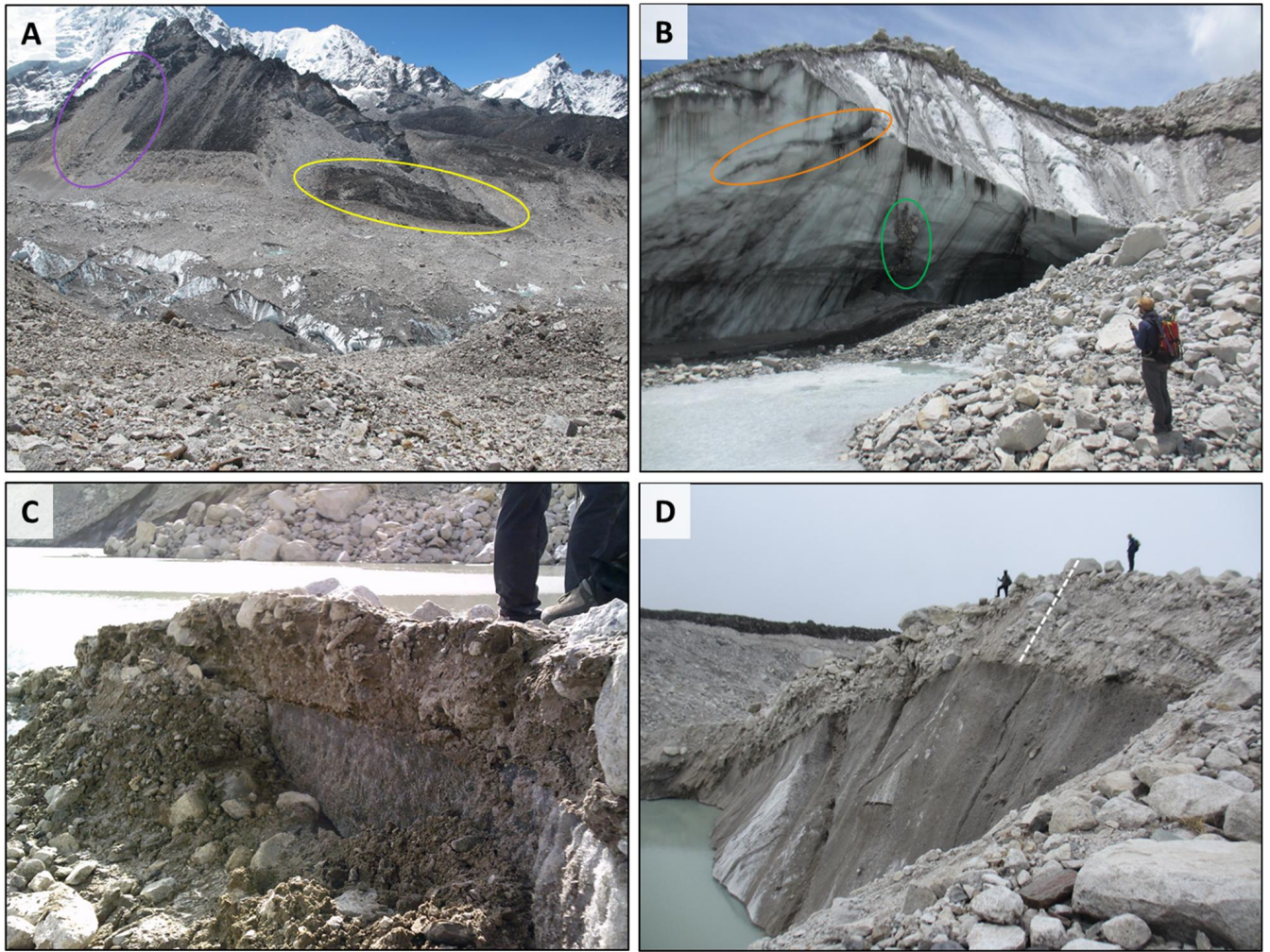

Figure 2 - Images illustrating variations in debris thickness over Khumbu Glacier, Nepal Himalaya: (A) a landslide scar (yellow circle) and unstable rock faces (purple circle) providing debris to the glacier surface; image is taken looking east across the surface of Khumbu Glacier, and the debris layer above ice cliffs can also be seen. (B) shows an ice cliff with entrained debris (green circle), debris-filled crevasse traces (orange circle), and a moderately-thick debris layer above ( 1-2 m); (C) a thin debris layer $(\sim 20 \mathrm{~cm})$ above ice adjacent to a supraglacial pond; and $(D)$ a thick debris cover (>5 metres, indicated by the white dashed line) above an ice cliff. Image credits: (A) DQ and (B-D) $K M$ 
The Cryosphere Discuss., https://doi.org/10.5194/tc-2017-210

Manuscript under review for journal The Cryosphere

Discussion started: 2 November 2017

(c) Author(s) 2017. CC BY 4.0 License.

(c) (1)

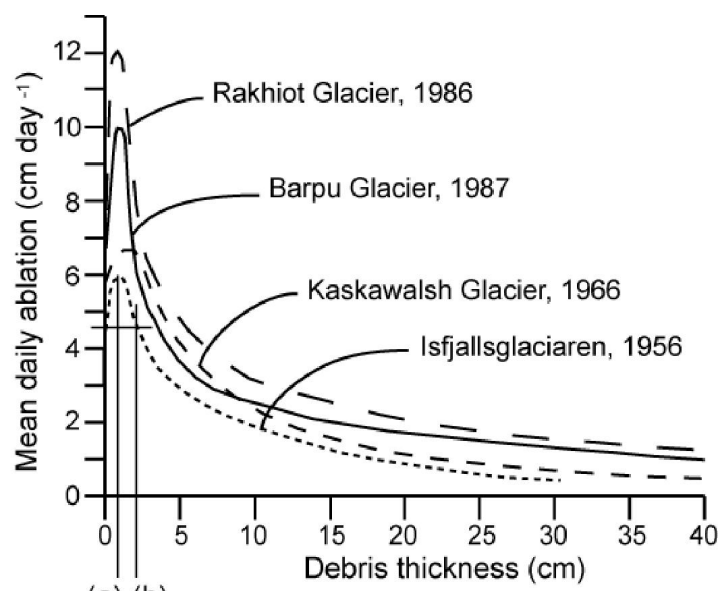

(a) (b)

1653

Figure 3 - Østrem curve examples from Nicholson \& Benn (2006, and citations therein), showing the variations in the relationship between debris thickness and ice ablation on different glaciers
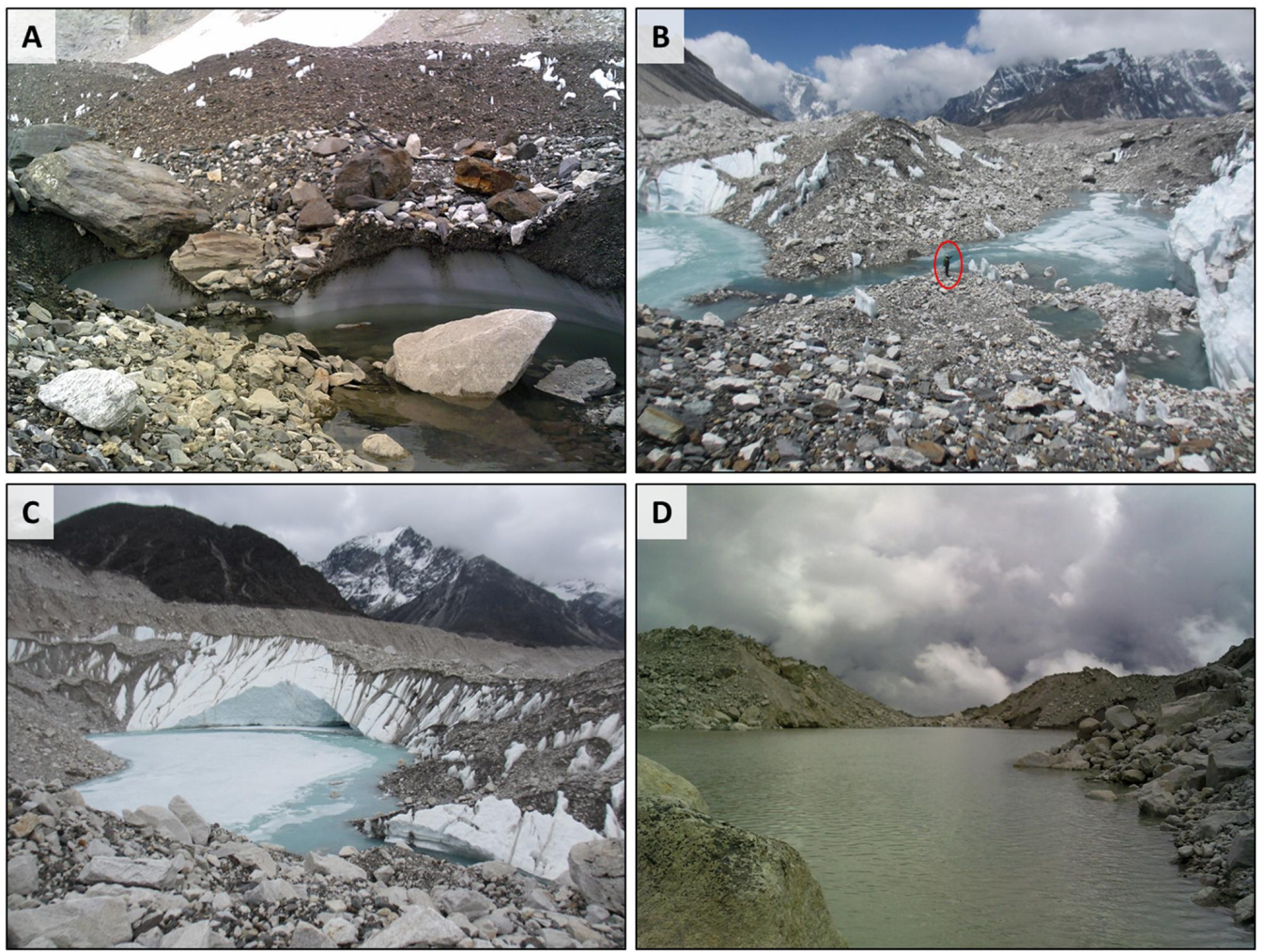
The Cryosphere Discuss., https://doi.org/10.5194/tc-2017-210

Manuscript under review for journal The Cryosphere

Discussion started: 2 November 2017

(c) Author(s) 2017. CC BY 4.0 License.

Figure 4-Examples of supraglacial ponds on Khumbu Glacier, Nepal Himalaya, ranging in diameter from several metres $(A)$, to tens of metres $(B, C)$ and hundreds of metres $(D)$. $(A)$ and $(C)$ also feature a notably large adjacent ice cliff system, relative to each pond/lake size; while (B) has a cliff system on the far of each of the lake sides (a person is circled for scale). Image credits: KM

1655
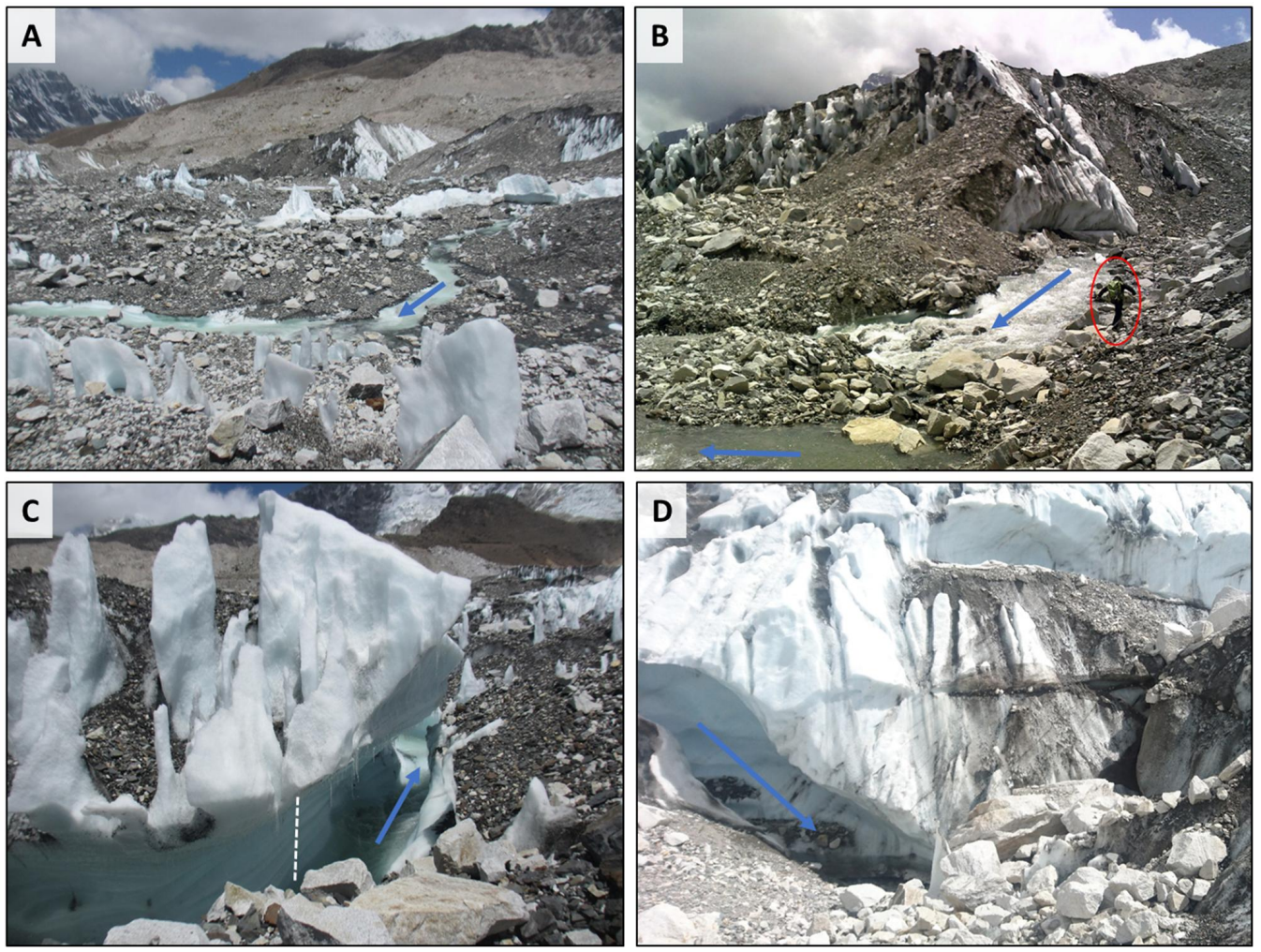

Figure 5 - Examples of a large supraglacial stream on Khumbu Glacier, Nepal Himalaya; blue arrows indicate water flow direction. (A) shows the stream in the upper ablation area; $(B)$ shows the stream again, approximately $2 \mathrm{~km}$ downstream of $(A)$ in the central ablation area and nearly twice the volume, just above a confluence with another large stream (bottom left of image; person shown for scale); (C) is an example of multiple levels of downcutting of the stream (grooves indicated by white dashed line, $1 \mathrm{~m}$ in height), slightly upglacier in location from (A); and (D) shows where this stream eventually disappears below the surface to become englacial, after several hundred metres of progressive downcutting, visible from the multiple relict levels. The drop in the channel is $\sim 10 \mathrm{~m}$, with the stream dropping another few metres beyond the boulders to the right of the image. Image credits: $(A-C) K M ;(D) E M$ 
The Cryosphere Discuss., https://doi.org/10.5194/tc-2017-210

Manuscript under review for journal The Cryosphere

Discussion started: 2 November 2017

(c) Author(s) 2017. CC BY 4.0 License.
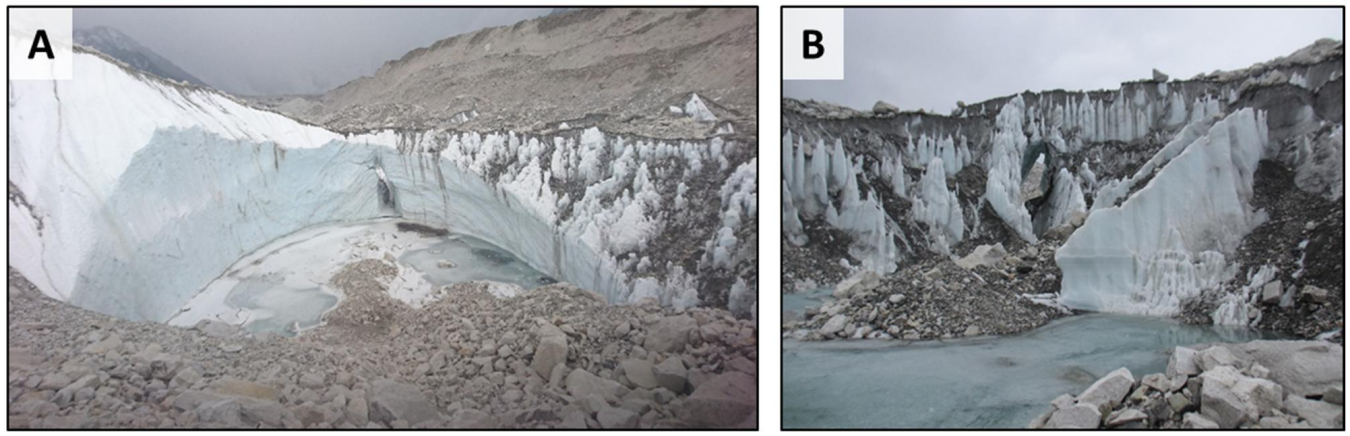

Figure 6-A relict englacial feature in the centre of an ice cliff on Khumbu Glacier, Nepal Himalaya, viewed (A) from upglacier, and (B) from downglacier. The associated supraglacial pond is hypothesised to have drained through this feature in the past. Following the drainage event, the pond water-level would have dropped, exposing the ice cliffs around its edge and resulting in the pond water-level being too low to sustain a water flow through the channel. On the downglacier side (B) a vast amount of surface lowering has occurred and the previously englacial channel is now visible from the surface. The relict channel could be seen to continue to meander and downcut for around $200 \mathrm{~m}$ further downglacier until joining a pond. The englacial feature is approximately 10 $m$ in height. Image credits: (A) EM; (B) KM
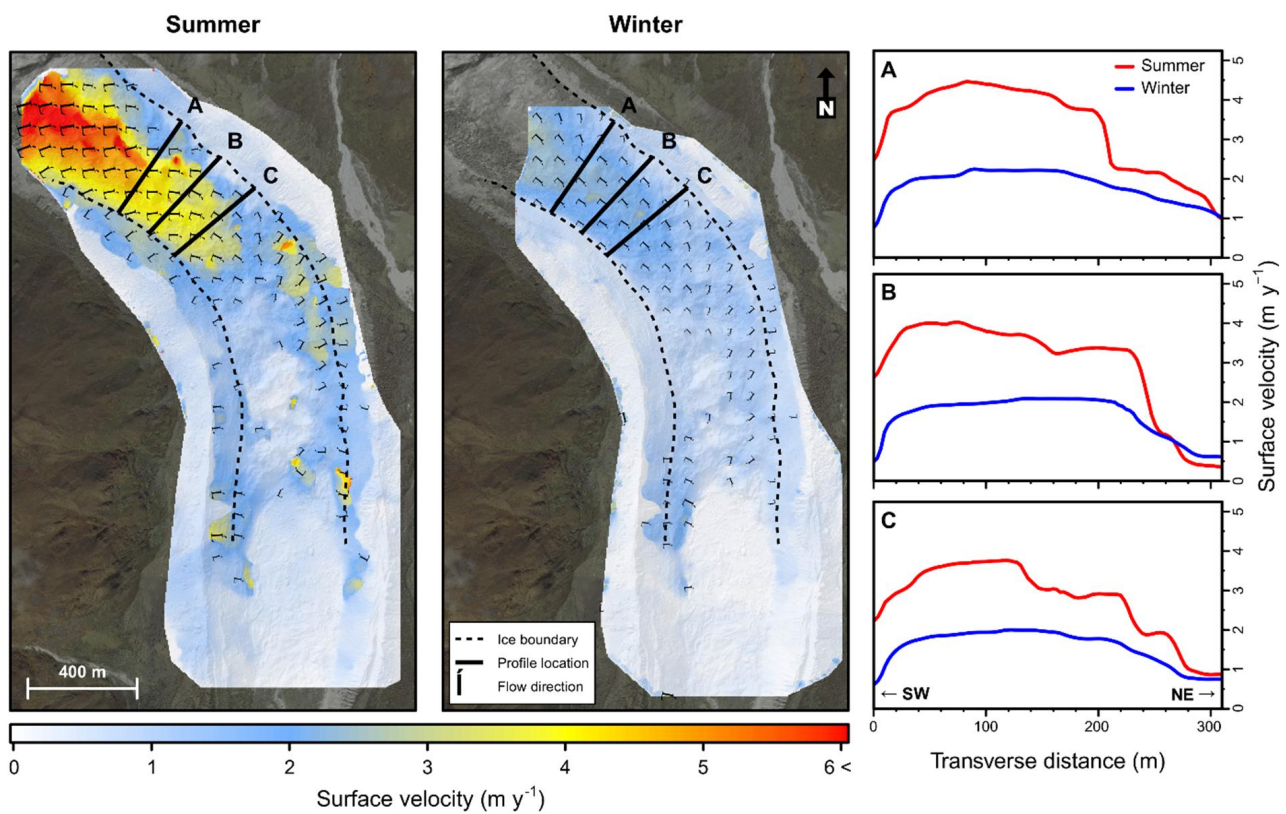

Figure 7 - Surface velocity maps of Lirung Glacier, Nepal Himalaya, from Kraaijenbrink et al. (2016b) during summer (left) and winter (right), with three transverse velocity profiles (A-C) at the locations marked. Available under a Creative Commons Attribution 4.0 License 
The Cryosphere Discuss., https://doi.org/10.5194/tc-2017-210

Manuscript under review for journal The Cryosphere

Discussion started: 2 November 2017

(c) Author(s) 2017. CC BY 4.0 License.

(c) $($ i)

1661

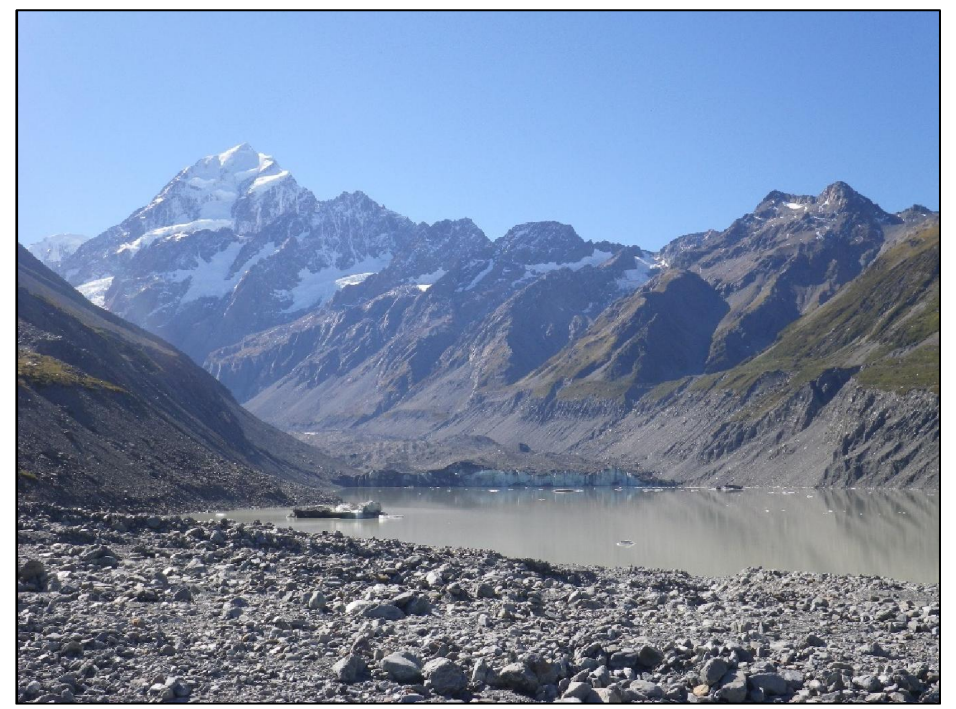

Figure 8-Image of Hooker Lake, a proglacial lake in front of the debris-covered Hooker Glacier, New Zealand Southern Alps, taken in 2013. For scale, the ice cliff at the terminus of the glacier is 30 $\mathrm{m}$ in height. Image credit: TIF 
The Cryosphere Discuss., https://doi.org/10.5194/tc-2017-210

Manuscript under review for journal The Cryosphere

Discussion started: 2 November 2017

(c) Author(s) 2017. CC BY 4.0 License.
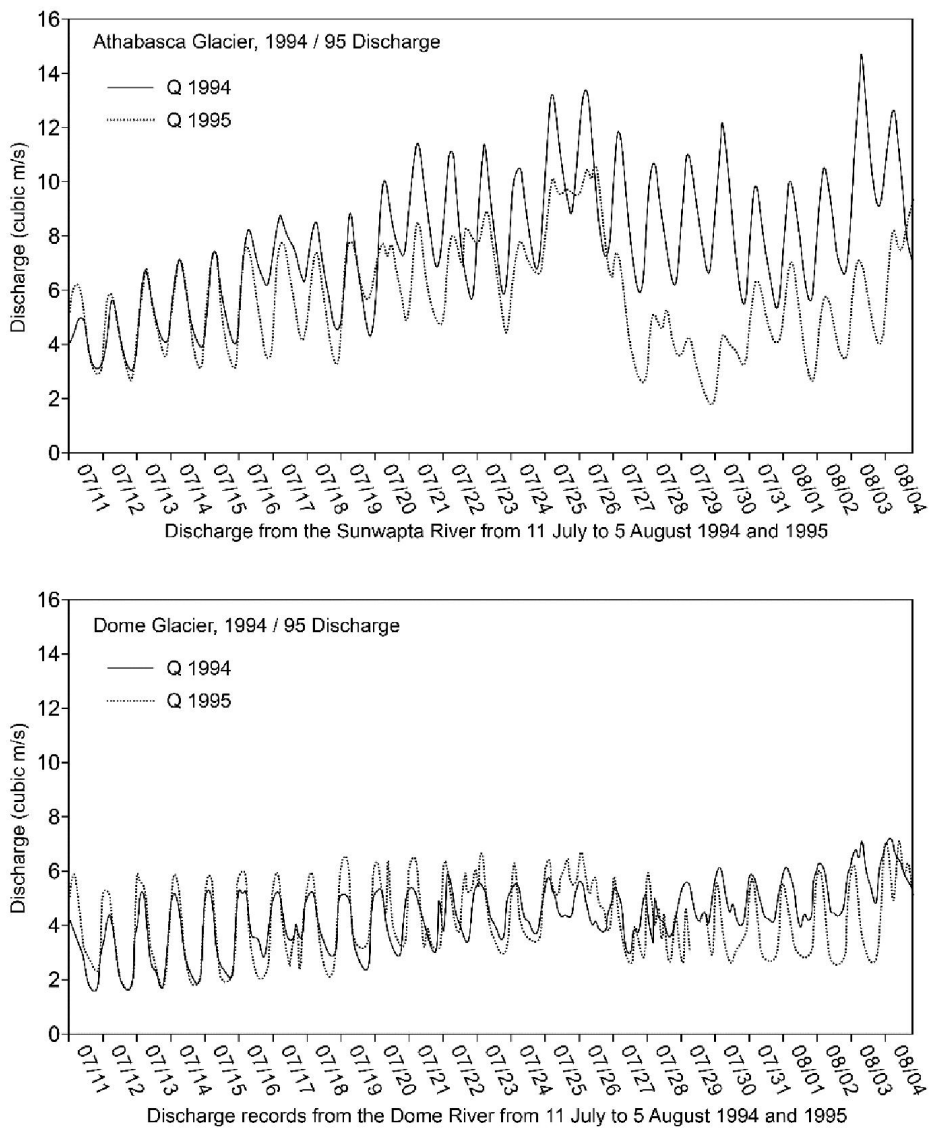

1664

Figure 9-Hydrographs of proglacial discharge of the clean-ice Athabasca Glacier and the adjacent debris-covered Dome Glacier, Canadian Rockies, over the ablation months of July and August 1994 and 1995. Figure redrawn from Mattson (2000) 
The Cryosphere Discuss., https://doi.org/10.5194/tc-2017-210

Manuscript under review for journal The Cryosphere

Discussion started: 2 November 2017

(c) Author(s) 2017. CC BY 4.0 License.

(c) (1)

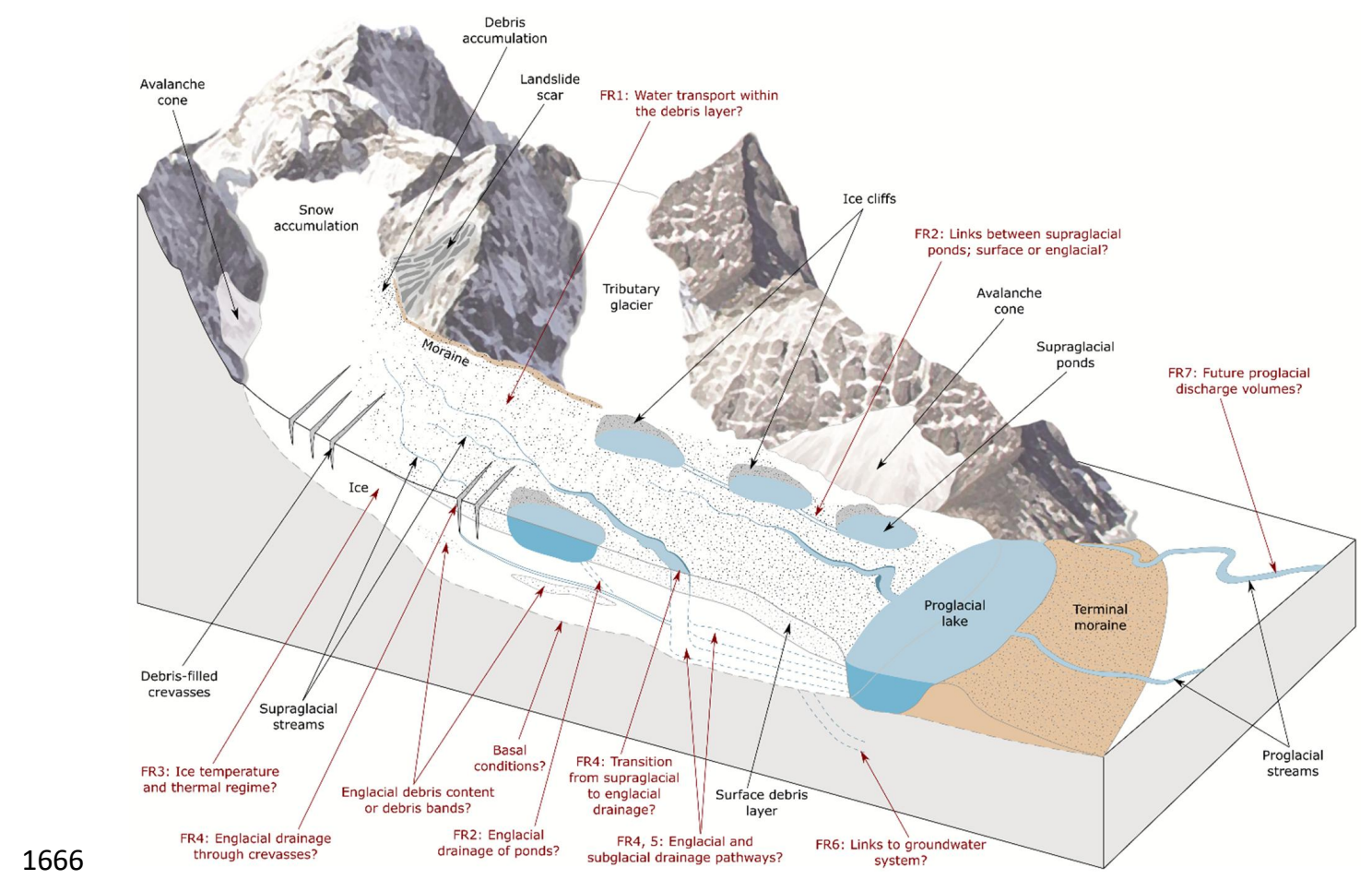

Figure 10-A conceptual illustration of the hydrological system of a DCG, including all known (black text), poorly understood and completely unknown potential hydrological features, highlighted in red text and linked to the Future Research (FR) areas for future hydrological research 